\title{
A concepção nietzschiana de ceticismo em Schopenhauer como educador*
}

\author{
Lorenzo Serini**
}

Resumo: O objetivo do presente ensaio consiste em esclarecer a concepção nietzschiana de ceticismo presente em Schopenhauer como educador - em especial, à luz do $\$ 3$ da aludida obra. Sem passar ao largo das principais preocupações de Nietzsche em sua filosofia de juventude como um todo, bem como do horizonte hermenêutico pós-kantiano que lhe é contemporâneo, o texto conta enfatizar que, na terceira Consideração extemporânea, Nietzsche está sobretudo preocupado com as consequências corrosivas do ceticismo à filosofia (e aos filósofos), e, potencialmente, à inteira cultura de sua época, razão pela qual estaria empenhado, já, na elaboração de uma sabedoria capaz de neutralizar tal periculosidade, fornecendo uma orientação aos nossos mais profundos e efetivos problemas vitais.

Palavras-chave: Schopenhauer, educação, ceticismo, póskantismo.

* Tradução de Fernando R. de Moraes Barros

** Professor da Universidade de Warwick, Coventry, Reino Unido.

ORCID https://orcid.org/0000-0003-3331-3401

Correio eletrônico: lorenzoserini24@gmail.com

Cad. Nietzsche, Guarulhos/Porto Seguro, v.40, n.3, p. 115-170, setembro/dezembro, 2019. | 115 
Serini, L.

\section{Introdução}

O problema do ceticismo desempenha um papel importante no período de juventude da filosofia de Nietzsche. Em Schopenhauer como educador (1874) e, com efeito, em diversos apontamentos póstumos da mesma época, Nietzsche afirma que dar uma resposta ao ceticismo constitui uma das tarefas essenciais da filosofia. ${ }^{1}$ Exploro, no presente artigo, a concepção nietzschiana de ceticismo contida em SE/Co. Ext. III §3. Tenciono iluminar a natureza do problema cético em tal obra - bem como em outros escritos de juventude - e tornar claro qual o papel do filósofo em relação ao ceticismo. Dirijo minha atenção particularmente a SE/Co. Ext. III §3, porque, a meu ver, é aqui que encontramos as referências mais significativas acerca do ceticismo nos textos de Nietzsche publicados no período de juventude, ${ }^{2}$ contendo informações relevantes a propósito tanto dos diferentes problemas filosóficos subjacentes à concepção nietzschiana de ceticismo quanto daquilo que ele considera ser a resposta filosófica mais adequada a eles.

A despeito da grande importância das declarações de Nietzsche sobre o ceticismo em SE/Co. Ext. III §3, elas foram amplamente negligenciadas na literatura secundária, em especial, na pesquisa acadêmica anglo-saxã. Uma das razões para tanto, creio, é o fato de que os comentadores estiveram geralmente mais propensos a associar Nietzsche ou ao ceticismo antigo - em especial, ao pirronismo ${ }^{3}$ - ou ao debate moderno e contemporâneo a respeito dos argumentos céticos em epistemologia e metafísica; ${ }^{4}$ ao passo que, tal como

1 Cf. SE/Co. Ext. III §3, KSA 1.355; Nachlass/FP 1872, 19[35], KSA 7.427 e 19[125], KSA 7.459.

2 A única outra referência importante ao ceticismo nos textos publicados de juventude é, tal como veremos mais adiante, em HL/Co. Ext. II (1874). Contudo, a discussão de Nietzsche em Schopenhauer como educador ressalta melhor o problema filosófico subjacente à sua concepção de ceticismo.

3 Cf. nomeadamente, Parush, 1976, pp. 523-542; Conway, 1992, pp. 193-223; Bett, 2000, pp. 62-86; Sommer, 2006, pp. 250-269; Sommer, 2018, pp. 442-453; Berry, 2011, pp. 497-514; Berry, 2014; Busellato 2012; Santini, 2013, pp. 368-274; Mitcheson, 2017, pp. 63-83 e Miner, 2018.

4 Cf. em especial, Poelner, 1995 e Doyle, 2009.

116 | Cad. Nietzsche, Guarulhos/Porto Seguro, v.40, n.3, p. 115-170, setembro/dezembro, 2019. 
veremos, na terceira Consideração extemporânea, Nietzsche faz intervir uma concepção um tanto idiossincrática de ceticismo, que diverge visivelmente dessas duas tradições céticas. Tratarei de destacar que a compreensão nietzschiana de ceticismo assemelhase, em todo caso, a uma específica tradição pós-kantiana. Nietzsche expõe explicativamente o ceticismo (bem como o relativismo) como sendo um efeito da filosofia kantiana, vinculando-o a uma experiência a um só tempo emocional e intelectual, por ele denominada "desespero da verdade" [Verzweiflung an der Wahrheit]. Nietzsche lida com o ceticismo de uma forma idiossincrática, pois assume um posicionamento híbrido a seu respeito: por um lado, sobretudo nos póstumos e textos não publicados, ele introduz argumentos céticos relativos à nossa possibilidade de conhecer a coisa-em-si; por outro lado, em SE/Co. Ext. III §3, considera o ceticismo como um perigo filosófico e pessoal aos pensadores, assim como uma ameaça potencial à inteira cultura da época. Nesse sentido, sugiro que Nietzsche concebe o ceticismo como uma daquelas doutrinas que ele toma "por verdadeiras, mas também mortais" em HL/Co. Ext. II. ${ }^{6}$ No ensaio sobre Schopenhauer, Nietzsche não está muito preocupado com a epistemologia ou, em geral, com um discurso

5 Cf. SE/Co. Ext. III 3, KSA 1.355. Por si só, a expressão "desespero pela verdade" captura propriamente a dupla dimensão dessa experiência, tanto epistêmica quanto afetiva: de um lado, diz respeito à verdade (ou, mais precisamente, a falta ou perda de uma verdade que se desejaria conhecer), e, de outro, refere-se ao sentimento de desespero. O vínculo entre ceticismo e desespero está, já, de algum modo, implícito no termo alemão que designa "desespero": Verzweiflung contém, de fato, a palavra Zweifel (dúvida). Na Alemanha, o sentimento de desespero acha-se, pois, semanticamente, ligado a um estado de dúvida. Nas línguas românicas, bem como no inglês, a palavra "desespero" deriva do verbo latino despêrare', composto pelo prefixo 'de-' usado para indicar privação e o verbo 'spērare' (esperar), que literalmente significa perder ou carecer de esperança. No sentido latino, o desespero é, portanto, o sentimento gerado pela ausência ou perda de esperança. Esse significado também está contido no termo alemão Verzweiflung. A propósito de um estudo sobre o conceito de desespero como dúvida e desesperança na história da filosofia e na psicopatologia contemporânea, cf. Bürgy, 2007, pp. 521-529.

6 Dentre elas, Nietzsche menciona "as doutrinas do vir-a-ser soberano, da fluidez de todos os conceitos, tipos e espécies, da falta de qualquer diferença cardinal entre o humano e o animal" (HL/Co. Ext. II 9, KSA 1.319).

Cad. Nietzsche, Guarulhos/Porto Seguro, v.40, n.3, p. 115-170, setembro/dezembro, 2019. | 117 
Serini, L.

filosófico propriamente acadêmico; a ele interessa, antes de mais nada, aquilo que poderíamos chamar de efeito prático do ceticismo causado pela filosofia kantiana sobre a vida humana, e, em especial, suas consequências éticas e existenciais. A resposta filosófica ao ceticismo proposta por Nietzsche em SE/Co. Ext. III §3 é, pois, assaz idiossincrática; trata-se, no meu entender, de uma resposta não estritamente epistêmica (tal como aquela atinente à maioria dos filósofos modernos e contemporâneos), mas tem a ver com sua concepção de filosofia como arte e sabedoria.

Esse artigo divide-se em quatro partes. Na primeira, esclareço as principais questões de Nietzsche em Schopenhauer como educador, a saber: o problema da educação, sua concepção de filósofo e sua crítica à filosofia acadêmica. Na segunda parte, mostro como o problema do ceticismo relaciona-se, em SE/Co. Ext. III §3, com cada um desses interesses centrais. Essas duas primeiras partes são essenciais para melhor compreender e apreciar o posicionamento híbrido de Nietzsche acerca do ceticismo enquanto algo verdadeiro, mas mortal. $\mathrm{Na}$ terceira parte, analiso os pressupostos teóricos, derivados da filosofia kantiana, que subjazem à concepção nietzschiana de ceticismo (e relativismo) em SE/Co. Ext. III §3, enfatizando, em especial, suas consequências axiológicas. A esse respeito, tratarei de sugerir que o problema do ceticismo antecipa, de modo intrigante, o problema do niilismo. Nessa parte, recorro e estabeleço um diálogo com Stefano Busellato e Luca Lupo, ${ }^{7}$ dois dentre os pouquíssimos estudiosos que dedicaram alguma atenção aos enunciados nietzschianos de juventude sobre ceticismo e relativismo em SE/Co. Ext. III §3. Na quarta parte, considero o papel que Nietzsche atribui ao filósofo no que concerne ao problema cético em SE/Co. Ext. III §3, bem como nos apontamentos póstumos. Na conclusão, especificarei o sentido no qual a idiossincrática concepção nietzschiana de ceticismo diverge das tradições céticas antigas e de inspiração cartesiana. Também

7 Cf. Busellato, 2012 e Lupo, 2019, pp.119-142.

118 | Cad. Nietzsche, Guarulhos/Porto Seguro, v.40, n.3, p. 115-170, setembro/dezembro, 2019. 
indicarei a importância da terceira Consideração extemporânea ao estudo do ceticismo nas obras tardias de Nietzsche.

\section{As principais questões de Nietzsche em Schopenhauer como educador: o problema da educação, sua concepção de filósofo e sua crítica à filosofia acadêmica.}

Permitam-me que comece por esclarecer aquilo de que Schopenhauer como educador não trata. Este último não versa, principalmente, sobre a filosofia de Schopenhauer, ao menos não num sentido convencional, acadêmico. Isso também salta imediatamente aos olhos de quem lê o texto; este contém apenas algumas poucas alusões às ideias básicas de Schopenhauer, que jamais são, contudo, cuidadosamente elaboradas. Chama atenção, em particular, a completa ausência de uma discussão acerca da metafísica schopenhaueriana da Vontade. Tal como podemos entrever a partir dos póstumos e da correspondência, Nietzsche de fato era, desde o início, cético em relação ao sistema metafísico de Schopenhauer (Cf. Nachlass/FP 1878, 30[9], KSA 8.524), sendo que pelo menos desde 1868 já rejeitara os pressupostos fundamentais da metafísica schopenhaueriana. Como bem se sabe, nos importantes apontamentos intitulados "Sobre Schopenhauer" [Zu Schopenhauer] (1868), Nietzsche empreende uma crítica dura e analítica à tentativa schopenhaueriana de caracterizar metafisicamente a coisa-em-si kantiana como Vontade, ${ }^{8}$ aplicando, em grande medida, como iremos ver, o argumento utilizado por

$8 C f$. o comentário de Christopher Janaway a esse respeito: “Assim, já em 1868, Schopenhauer surge nos apontamentos de Nietzsche como um oponente filosófico, sustentando, a ser assim, um ataque ao sistema nervoso central, um ataque que deveria nos fazer duvidar se Nietzsche chegou, em algum momento, a aderir seriamente à metafísica schopenhaueriana da Vontade, e isso mesmo lá, nos escritos iniciais, que corroboram e são ostensivamente corroboradas por Schopenhauer, a saber, em $O$ nascimento da tragédia (1872) e em suas Considerações extemporâneas, com seu ensaio 'Schopenhauer como educador', de 1874” (Janaway 1998, p.19).

Cad. Nietzsche, Guarulhos/Porto Seguro, v.40, n.3, p. 115-170, setembro/dezembro, 2019. | 119 
Serini, L.

Kant e, em especial, por Lange para denegar qualquer forma de conhecimento transcendente ou metafísico. ${ }^{9}$

Em tais apontamentos, Nietzsche tenciona não obstante esclarecer que sua crítica não compromete seu respeito por Schopenhauer, nem abala o valor global de seu ensinamento: "os equívocos dos grandes homens [como Schopenhauer] são admiráveis, porque são mais férteis que as verdades dos homens menores" (Cf. Nietzsche, 2009, p.3; Nachlass/FP 1867-1868, 57 (55), KGW I, 4.418-43). Numa reveladora carta enviada à Cosima Wagner, em 1876, Nietzsche confessa que, quando do período em que escrevia a terceira Consideração extemporânea, ele já havia abandonado tudo o que dizia respeito ao dogma filosófico schopenhaueriano, elucidando que aquilo que lhe realmente importava era, em vez disso, o ser humano $\left(C f\right.$. carta ${ }^{\circ} 581$ à Cosima Wagner, a 19 de dezembro de 1876, KSB 5.210). Em que sentido, em 1874, Nietzsche estimava Schopenhauer como um ser humano e não em função do conteúdo filosófico de seu sistema e, sobretudo, por conta de sua metafísica? Tal sugeriu Christopher Janaway, em Schopenhauer como educador Nietzsche se vale principalmente de "Schopenhauer como [um] exemplar": aqui, a "figura de Schopenhauer funciona como um símbolo instrutivo e uma encarnação da vida intelectual alemã e européia. ${ }^{10}$ Tal como o próprio Nietzsche esclarecerá em seu ensaio, o valor exemplar e

9 Numa relevante carta de 1866, Nietzsche resume com entusiasmo os principais resultados do neokantismo de Lange em sua História do materialismo, associando-os à filosofia de Schopenhauer. Segundo Nietzsche, Lange demonstra que nossa representação do mundo é determinada por nossa organização psicofísica e que, por conta disso, "a verdadeira essência das coisas, a coisa em-si," nos é desconhecida ( $c f$. carta ${ }^{\circ} 517$ a Carl von Gersdorff, do fim de agosto 1866, KSB 2.159). Nos escritos de juventude, tal como esclarecerei na terceira seção do presente artigo, Nietzsche concebe o ceticismo precisamente como um efeito dessa declaração derivada da filosofia kantiana.

10 Cf. Janaway, 1998, pp. 14-15. Poder-se-ia argumentar que, na Terceira consideração extemporânea, Nietzsche vale-se de Schopenhauer de uma maneira monumental. Ele se volta a Schopenhauer, porque precisa de figuras exemplares, professores e consoladores, mas é incapaz e encontrá-los entre seus contemporâneos e no presente ( $c f$. HL/Co. Ext. II 2, KSA 1.258). Num certo sentido, tal como a pessoa que contempla a história de forma monumental, Nietzsche distorce, reinterpreta e cria um mito a partir de Schopenhauer, ignorando partes da filosofia schopenhaueriana ( $c f$. HL/Co. Ext. II 2, KSA 1.262).

120 | Cad. Nietzsche, Guarulhos/Porto Seguro, v.40, n.3, p. 115-170, setembro/dezembro, 2019. 
educativo de Schopenhauer reside no modo como ele viveu como um legítimo filósofo, quer dizer, enquanto um pensador extemporâneo, "livre tanto do espírito de sua época quanto do medo de tal espírito" (SE/Co. Ext. III 8, KSA 1.425), como alguém que não se deixou emaranhar em conceitualizações escolásticas e obscuridades da filosofia acadêmica ( $c f$. SE/Co. Ext. III 3, KSA 1.357), mas enxergou genuinamente os problemas da vida e da existência ( $c f$. SE/Co. Ext. III 3, KSA 1.360), com um estilo honesto e autenticamente jovial ( $c f$. SE/Co. Ext. III 2, KSA 1.350). Assim, para Nietzsche, Schopenhauer é mais valioso como um exemplar de filósofo livre e autêntico ( $c f$. SE/Co. Ext. III 3, KSA 1.362), que, de forma heróica, consagrou sua vida à verdade ou, mais precisamente, à veracidade ( $c f$. SE/Co. Ext. III 4, KSA 1.363-75; SE/Co. Ext. III 7, KSA 1.411).

Embora Nietzsche enfoque, na terceira Consideração extemporânea, o exemplo educativo de Schopenhauer enquanto ser humano - em vez de mirar em sua metafísica da Vontade ou noutras doutrinas contidas em $O$ mundo como Vontade e representação, é importante notar que ele ainda admira profundamente alguns elementos da filosofia schopenhaueriana, em especial, os Parerga e Paralipomena (1851). Tal como se tornará mais patente, Nietzsche dialoga diretamente com os pensamentos de Schopenhauer acerca do aprendizado e da educação, ${ }^{11}$ com sua tentativa de elaborar uma sabedoria de vida, ${ }^{12}$ sua crítica à filosofia acadêmica ${ }^{13}$ e seu comprometimento com a virtude intelectual do pensar por si próprio. ${ }^{14}$

Em seu comentário retrospectivo às Considerações extemporâneas, em Ecce Homo (1888/1904), Nietzsche declara que Schopenhauer como educador trata de três questões principais:

11 Cf. Schopenhauer, v. II, 1974 (d) e Schopenhauer, v. II, 1974 (e).

12 Cf. Schopenhauer, vol. I, 1974 (b).

13 Cf. Schopenhauer, vol. I, 1974 (c) e Schopenhauer, vol. II, 1974 (d).

14 Cf. Schopenhauer, vol. II, 1974 (f). Nietzsche deve ter lido esse texto junto com o ensaio "SelfReliance" ["Autoconfiança"] (1841), de Emerson.

Cad. Nietzsche, Guarulhos/Porto Seguro, v.40, n.3, p. 115-170, setembro/dezembro, 2019. 121 
primeiro, "o problema da educação"; segundo, sua compreensão de filósofo enquanto "um terrível explosivo que coloca tudo em perigo"; 15 e, terceiro, sua critica à filosofia acadêmica, incluindo até mesmo Kant (EH/EH, As extemporâneas 3, KSA 6.320). Além disso, Nietzsche explica que, em tal escrito, seu maior propósito é o de apontar para "um conceito mais elevado de cultura" (EH/EH, As extemporâneas 1, KSA 6.316). Tais interesses, como tenciono sugerir, acham-se intimamente ligados às declarações de Nietzsche sobre o ceticismo em SE/Co. Ext. III §3. É, pois, importante considerá-los inicialmente, para então melhor compreender e apreciar o problema do ceticismo em tal obra.

Devo ater-me, primeiro, ao problema da educação [Erziehung], que desempenha um papel central no título - associado à figura de Schopenhauer -, assim como ao longo de todo o ensaio. ${ }^{16}$ Entende-se, por esse termo, tanto educação de si mesmo (ou auto-cultivo de si) quanto educação do público leitor, ou, quiçá, da inteira humanidade. O §1 inicia-se com uma densa discussão a respeito da educação de si, entendida como a busca pela própria singularidade, isto é, por aquilo que é único no indivíduo e o distingue dos demais. A busca pelo si próprio mais singular - que Nietzsche também chama de "si mesmo autêntico", "verdadeiro ser" (Cf. SE/Co. Ext. III 1, KSA 1.340), ou, então, "si mesmo superior"17 - adquire a forma de um

15 Como veremos, essa definição de filósofo ecoa diretamente a citação de Nietzsche, em Schopenhauer como educador (1841), do ensaio "Círculos" (1841), de Emerson.

160 problema da educação, creio, permanece uma preocupação principal na inteira obra de Nietzsche.

17 Cf. SE/Co. Ext. III 1, KSA 1.340; SE/Co. Ext. III 6, KSA 1.385. Dever-se-ia sublinhar que aquilo que Nietzsche chama de "verdadeiro ser", "ser autêntico" ou "si mesmo superior" não constitui uma essência metafísica tal como esta é compreendida pela tradição metafísica; não se trata, por exemplo, de algo substancial que existe e que, qual uma alma imortal, acha-se escondido no interior de nós mesmos. O jovem Nietzsche rejeita completamente qualquer tentativa tradicional e metafísica de determinar a natureza de coisas para além da experiência possível, tal como uma alma imortal. A singularidade própria é, antes do mais, uma dimensão potencial de nosso si mesmo, quer dizer, aquilo que ele aqui e agora ainda não é, mas poderá vir a se tornar ao longo do processo de educação. O cultivo da própria singularidade conduz, pois, a uma transformação de si, rumo a um si mesmo que é superior em relação àquilo que, comum e imediatamente, tomamos por nós próprios. Assim, 
processo de como aprender a pensar e agir por si mesmo, em vez de se conformar ociosamente às opiniões e costumes da maioria $(C f$. SE/Co. Ext. III 1, KSA 1.337). Tal como assevera Nietzsche, essa busca pela própria singularidade constitui um "terrível esforço" e uma espécie de "tarefa" (Cf. SE/Co. Ext. III 2, KSA 1.343), já que somos "responsáveis por nossa existência diante de nós mesmos" (Cf. SE/Co. Ext. III 1, KSA 1.339). A fim de fazer justiça à nossa singularidade, Nietzsche defende que deveríamos pensar por nós mesmos e "viver de acordo com nossos próprios padrões e leis" (Cf. SE/Co. Ext. III 1, KSA 1.339), dedicando-nos à "incondicional honestidade e nudez"18 apesar de suas dificuldades.

No $§ 6$, Nietzsche distingue três fases principais no processo da educação: primeiro, o auto-conhecimento; segundo, a identificação de um grande ser humano como um educador; e, terceiro, a ação (Cf. SE/ Co. Ext. III 6, KSA 1.386; SE/Co. Ext. III 3, KSA 1.353). O segundo e terceiro momentos da educação, sublinha Nietzsche, sancionam a entrada do indivíduo no território da cultura. Ao buscarmos e cultivarmos nossa própria singularidade, terminamos por ir além da estreiteza daquilo que fazemos, pensamos e desejamos aqui e agora, no cumprimento indolente dos modos habituais de pensar e viver, encontrando algo de "mais elevado e mais humano" para além de nós mesmos (Cf. SE/Co. Ext. III 6, KSA 1.385). Dessa maneira, nos é dado conhecer grandes seres humanos, comprometendo-nos com aquilo que é raro e grandioso na cultura - com ideias e feitos originais e notáveis. Sob a ótica de Nietzsche, esses grandes seres humanos desempenham um papel importante na educação, ao liberarem o si

\footnotetext{
o si mesmo autêntico ou superior está para além e acima daquilo que, agora, fazemos, pensamos e desejamos sob a autoridade e adesão às opiniões e costumes convencionais. Esse interesse antecipa, sob vários aspectos, o existencialismo. Sobre a relação de Nietzsche com este último e sua preocupação acerca da respectiva noção central de autenticidade, $c f$. Ansell-Pearson, 2014.
}

18 Cf. SE/Co. Ext. III 1, KSA 1.337. Essa honestidade incondicional acha-se vinculada, por um lado, à honestidade de Schopenhauer (e de Montaigne) ( $c f$. SE/Co. Ext. III 2, KSA 1.348) e, por outro, à sua veracidade ( $c f$. SE/Co. Ext. III 4, KSA 1.372).

Cad. Nietzsche, Guarulhos/Porto Seguro, v.40, n.3, p. 115-170, setembro/dezembro, 2019. | 123 
Serini, L.

mesmo de seus aspectos convencionais e, ao mesmo tempo, elevaremno rumo a uma dimensão, em direção a novas possibilidades de viver e pensar (Cf. SE/Co. Ext. III 1, KSA 1.337-38). De acordo com a visão nietzschiana, a fase mais difícil e relevante no processo de educação é a terceira e última. Alcançado esse estágio, os indivíduos cultivam a si mesmos e buscam seu si mesmo superior. Mas, para Nietzsche, eles "não podem deter-se" no auto-cultivo de si (Cf. SE/ Co. Ext. III 6, KSA 1.387). A educação requer, antes de tudo, a ação desses indivíduos, a começar por uma contribuição ativa à cultura sob a forma de uma crítica cultural, quer dizer, a oposição "àquelas influências, leis do hábito e instituições" (SE/Co. Ext. III 6, KSA 1.386) que representam uma ameaça à saúde e florescimento da cultura.

Aqui, o problema da educação converge com o problema da cultura [Kultur]. Ao atravessar o processo educativo, o indivíduo "coloca-se no interior do círculo da cultura" (SE/Co. Ext. III 6, KSA 1.385). Assim, ao fim e ao cabo desse terceiro estágio, a tarefa de educar-se a si mesmo conduz à tarefa cultural de educar o público leitor, um determinado povo e, até mesmo, a inteira humanidade (Cf. SE/Co. Ext. III 3, KSA 1.362). Nietzsche caracteriza essa tarefa, em especial, como uma "educação moral" (Cf. SE/Co. Ext. III 2, KSA 1.345), a qual visa a fornecer ideais éticos e indicar novos modos de vida. Assim como a educação do indivíduo aponta para um si mesmo mais elevado, a educação da humanidade aponta para uma forma mais elevada de vida e cultura - ou, como Nietzsche escreverá em Wagner em Bayreuth (1876), para uma "humanidade mais livre" e "melhor" (WB/Co. Ext. IV 10, KSA 1.504). De acordo com o filósofo alemão, apenas alguns poucos grandes seres humanos são capazes de levar a efeito essa tarefa educativa. Dirigindo-se à conclusão do texto, Nietzsche então explica o significado destes últimos à cultura, 


\author{
citando, para tanto, uma passagem do ensaio de Emerson intitulado \\ "Círculos": ${ }^{19}$
}

(...) quando o poderoso Deus permite a chegada de um pensador em nosso planeta. Então, tudo está em perigo (...) Todas as coisas que, em tal momento, parecem caras e valiosas ao ser humano, elas assim o são por conta das ideias que emergiram em seu horizonte espiritual, que causam a atual ordem das coisas tal como uma árvore carrega suas maçãs. Um novo grau da cultura iria revolucionar instantaneamente o inteiro sistema dos esforços humanos (Cf. SE/Co. Ext. III 8, KSA 1.426)

Pensadores verdadeiramente originais e criativos, assevera Nietzsche, são extemporâneos; eles olham acima e para além da atual ordem das coisas, colocando-a em perigo e, inclusive, levando-a à destruição. ${ }^{20}$ Suas maiores ideias podem ter o poder transformador apto a dar forma à cultura e, com esta, à inteira organização da vida humana. ${ }^{21}$

Essa citação nos conduz à segunda principal preocupação nietzschiana em Schopenhauer como educador: sua concepção de filósofo. Em Ecce homo, vale lembrar, Nietzsche escreve que, na terceira Consideração extemporânea, ele compreende o filósofo como

19 Acerca da relação entre Nietzsche e Emerson, $c f$. Stack, 1992 e Zavatta, 2019.

20 Cf. também Nachlass/FP 1874, 34 [8], KSA 7.794. Nietzsche insinua que esses grandes seres humanos, ao adotarem uma perspectiva inteiramente nova sobre as coisas, introduzem uma dimensão mais elevada na vida humana, contribuindo à transfiguração, aprimoramento e perfeição da natureza. Cf. HL/Co. Ext. II 10, KSA 1.324; SE/Co. Ext. III 1, KSA 1.341.; SE/Co. Ext. III 3, KSA 1.350 e SE/Co. Ext. III 5, KSA 1.375. Nesse ponto, Nietzsche está revivificando a antiga concepção grega de physis, entendida como o âmbito de crescimento e surgimento da vida e de todas as coisas, em oposição a nomos, esfera das leis e convenções humanas. $C f$., por exemplo, Nachlass/FP 1872, 19[266], KSA 7.502. Tanto no ensaio como nos apontamentos, Nietzsche refere-se frequentemente a essa tarefa como "metafísica", mas compreendendo-a especificamente como "algo que é explicável somente mediante as leis de uma outra e mais elevada vida, afirmadora à luz da mais profunda compreensão - ainda que tudo aquilo que ele faça pareça ser a destruição e violação das leis desta vida" (SE/Co. Ext. III 4, KSA 1.372). Sobre a específica compreensão nietzschiana da tarefa da filosofia como uma tarefa metafísica, em oposição à metafísica tradicional e inclusive à sua assim chamada metafísica de "artista", $c f$. Ansell-Pearson, 2008, pp. 767-99.

21 Nietzsche acredita que a transformação cultural tem prioridade sobre a transformação política $(c f$. SE/Co. Ext. III 4, KSA 1.363). Cf. também FW/GC 100, KSA 3.457.

Cad. Nietzsche, Guarulhos/Porto Seguro, v.40, n.3, p. 115-170, setembro/dezembro, 2019. 125 
Serini, L.

"um terrível explosivo que coloca tudo em perigo" (EH/EH, As extemporâneas 3, KSA 6.320). Em tal ensaio - e, provavelmente, em sua inteira obra -, Nietzsche considera a filosofia como inseparável da "tarefa de educar um ser humano para tornar um ser humano". ${ }^{22} \mathrm{De}$ fato, Nietzsche concebe o "verdadeiro filósofo como [um] educador" (Cf. SE/Co. Ext. III 2, KSA 1.346) e defende Schopenhauer como um exemplo de tal "educador e filósofo" (Cf. SE/Co. Ext. III 2, KSA 1.350). Este último, a seu ver, representa tanto o educador pessoal, que o ajudou a se tornar quem ele é (segunda fase do processo educativo), como também, num sentido mais geral, o exemplar de um autêntico filósofo, que toma sobre si a tarefa de educar os seres humanos, apontando para um conceito mais elevado de cultura. Uma das declarações fundamentais de Nietzsche no ensaio é a de que a maneira como Schopenhauer praticou e viveu a filosofia ilustra o papel mesmo que o filósofo deveria desempenhar.

Nas linhas que se seguem, devo pontuar alguns dos aspectos mais importantes da compreensão nietzschiana acerca da tarefa da filosofia, do papel do filósofo em Schopenhauer como educador e, sob um ângulo mais geral, nas Considerações extemporâneas:

- A filosofia começa com o problema da existência, o qual confronta nada menos que a todos os seres humanos. Esse problema inclui questões tais como "Por que estou vivo? Que lição a vida deveria ensinar-me? Como me tornei aquilo que sou e por que sofro por ser quem sou? (...) Por que vives?" (SE/ Co. Ext. III 4, KSA 1.374) e "qual é o valor da vida em geral?" (SE/Co. Ext. III 3, KSA 1.363). A filosofia deveria ser buscada

22 SE/Co. Ext. III 2, KSA 1.343. Com isso, Nietzsche alinha-se com alguns pensadores alemães proeminentes do século XVII e XVIII (ex: Herder, Humboldt, Schiller, os românticos e, em certa medida, Schopenhauer), os quais atribuíram uma importância central à ideia de cultivo (Bildung) - e de educação (Erziehung) - tanto de si mesmo quanto da inteira humanidade. A propósito da centralidade do conceito de educação na filosofia de Nietzsche e sobre sua contribuição ao discurso filosófico acerca da Bildung (e da Erziehung), cf., por exemplo, Gjedal, 2015, pp. 712-716.

126 | Cad. Nietzsche, Guarulhos/Porto Seguro, v.40, n.3, p. 115-170, setembro/dezembro, 2019. 
em relação a tais questões concernentes à vida humana, e não em isolamento relativamente a elas - as quais, como vimos, também constituem o cerne do problema da educação.

- $\quad$ À luz disso, a filosofia não é nem uma simples profissão nem um assunto exclusivamente intelectual; antes do mais, ela afeta o ser humano integralmente, como um sujeito que pensa, age e vive: "um filósofo não é meramente um grande pensador, senão que também um genuíno ser humano" (SE/Co. Ext. III 7, KSA 1.410). A teoria deveria intensificar a prática $(C f$. HL/Co. Ext. II 7, KSA 1.295), aumentando ou estimulando diretamente a atividade de um pensador (Cf. HL/Co. Ext. II Prefácio, KSA 1.245). Nesse sentido, a filosofia configura-se a si mesma como uma forma de cultivo de si e de educação do indivíduo à vida e à ação.

- Assim, a filosofia deveria ser praticada como um modo de vida, e não apenas como uma disciplina acadêmica: "a única crítica possível de qualquer filosofia, a única a provar alguma coisa, é tentar descobrir se nos é dado viver de tal filosofia, e isso jamais foi ensinado em qualquer universidade (SE/Co. Ext. III 8, KSA 1.417)." No entanto, cumpre ter em mente que a concepção inicial de Nietzsche acerca da filosofia como modo de vida é diferente daquela dos antigos, e, em especial, da concepção das escolas helênicas. À diferença dos antigos, o jovem Nietzsche acredita que a filosofia não deve visar prioritariamente à felicidade ou à tranquilidade pessoal, mas, antes disso, uma vida nova e mais elevada, e isso não só com vistas ao indivíduo (auto-cultivo), senão que também à inteira humanidade (Cf. HL/Co. Ext. II 5, KSA 1.279). Verdadeiros filósofos como Schopenhauer, dirá Nietzsche, buscam heroicamente a filosofia a despeito de todo sofrimento inerente à veracidade, acolhendo-o inclusive voluntariamente 
Serini, L.

em si mesmos em prol da honestidade filosófica (Cf. SE/Co. Ext. III 4, KSA 1.363).

- A filosofia deveria visar à sabedoria (conhecimento à vida) e não somente ao conhecimento. ${ }^{23}$ Tal saber filosófico deveria considerar o conhecimento a serviço dos problemas e necessidades da vida humana, fornecendo orientações sobre como viver. ${ }^{24}$ Essa busca requer uma atenção urgente a "questões morais" e não apenas a problemas do conhecimento (Cf. SE/ Co. Ext. III 2, KSA 1.341). Isso não deveria restringir-se ao discurso acadêmico e formal acerca dos temas da moral, senão que, ao contrário, comprometer-se com aquilo que Nietzsche denomina "moralidade criativa", quer dizer, com o esforço criativo para estabelecer novos ideais éticos de acordo com os quais as pessoas possam viver $(C f$. SE/Co. Ext. III 2, KSA $1.341)$.

- A filosofia não deveria estar confinada aos debates acadêmicos nas universidades, mas "ter um impacto no mundo externo", sobre o filósofo como um ser humano e, até mesmo, sobre a inteira cultura de sua época (Cf. HL/Co. Ext. II 7, KSA 1.295). Nesse sentido, a filosofia se configura como uma forma de educação ou cultivo do público leitor e, em larga escala, da humanidade como um todo (Cf. SE/Co. Ext. III 2, KSA 1.341).

- A filosofia deveria leva a cabo uma série de tarefas envolvidas na concepção nietzschiana de filósofo como "médico da cultura" (Nachlass/FP 1873, 23[15], KSA 7.545): empreender o diagnóstico da doença cultural de sua época (Cf. SE/Co. Ext. III 2, KSA 1.341 e SE/Co. Ext. III 6, KSA 1.383), efetuar a crítica à cultura (Cf. SE/Co. Ext. III 6, KSA 1.383) e contribuir

23 Cf. Ansell-Pearson, 2018, pp. 56-57.

24 Cf. SE/Co. Ext. III 6, KSA 1.383; cf. também Nachlass/FP 1874, 30[15], KSA 7.737-38 e Nachlass/ FP 1875, 6[4], KSA 8.97-8.

128 | Cad. Nietzsche, Guarulhos/Porto Seguro, v.40, n.3, p. 115-170, setembro/dezembro, 2019. 
A concepção nietzschiana de ceticismo em Schopenhauer como educador

à transformação e aprimoramento da cultura e dos seres humanos (Cf. SE/Co. Ext. III 2, KSA 1.341 e SE/Co. Ext. III 8, KSA 1.411). Tal como Nietzsche diz na Quarta consideração extemporânea: "a questão mais importante em toda filosofia é em que medida as coisas possuem uma natureza e uma forma inalterável, de sorte que, uma vez respondida essa pergunta, nos seja dado proceder, com coragem implacável, ao aprimoramento daquele aspecto do mundo reconhecido como alterável." (WB/ Co. Ext. IV 3, KSA 1.445)

Como se percebe, ao descrever a figura do legítimo filósofo, Nietzsche também observa aquilo que a filosofia não deveria ser. Opõe, sobretudo, o exemplo da vida filosófica de Schopenhauer ao modo como a filosofia é, de acordo com a moda, praticada e ensinada nas instituições alemães no século XVIII, acusando os eruditos de terem negligenciado gravemente as tarefas filosóficoeducativas mais importantes. Nisso consiste a terceira principal preocupação de Schopenhauer como educador. Uma das maiores alegações das Considerações extemporâneas é, com efeito, o fato de o conhecimento científico [Wissenschaft] - particularmente, a filologia, a historiografia científica e a filosofia acadêmica - falhar na tentativa de educar genuinamente os seres humanos, mostrando-se, inclusive, prejudicial ou nociva à cultura e humana, na medida em que engendra uma nova forma de barbarismo. Em contrapartida, o ensaio sobre Schopenhauer exorta sobretudo "um modo completamente inconvencional de reflexão [filosófica] (...) no intuito de evitar e mirar para além de nossa atual instituição educacional" (SE/Co. Ext. III 6, KSA 1.401). Mas quem são, afinal de contas, tais filósofos acadêmicos contra os quais Nietzsche opõe Schopenhauer como o exemplar do verdadeiro filósofo?

Tal como observou recentemente Frederick Beiser, na segunda metade do século XIX, após o declínio do idealismo especulativo e 
Serini, L.

do romantismo, teve início um período neo-kantiano da universidade alemã. ${ }^{25}$ Acadêmicos neo-kantianos voltaram-se ao criticismo de Kant a fim de reconsiderar a relação entre a filosofia e as ciências positivas; estas últimas haviam se tornado independentes da filosofia, inclusive assumindo a autoridade de áreas que previamente eram de sua competência. ${ }^{26}$ Os neo-kantianos, descreve Beiser, concebiam a filosofia sobretudo como epistemologia ou teoria do conhecimento e, mais especificamente, como um exame crítico dos métodos e princípios da ciência, valendo-se de Kant para investigar a confiabilidade das explicações científicas. ${ }^{27}$ Beiser aponta que, inicialmente, os estudiosos neo-kantianos privilegiavam quase que exclusivamente o lado teórico da filosofia, passando gravemente ao largo de questões sobre ética, política e estética, sendo que, quando passaram a considerar o seu lado prático, em resposta ao desafio colocado pelo surgimento do pessimismo na cultura alemã (em meados dos anos de 1860), seus esforços terminaram por se mostrar amplamente desapontadores e pouco originais. ${ }^{28}$ Quando Nietzsche fala sobre filósofos acadêmicos, creio, ele se refere frequentemente a tais estudiosos neo-kantianos (Cf., em especial, SE/Co. Ext. III 8, KSA 1.472). Embora tivesse, nos primeiros escritos, uma admiração entusiástica por Lange (um pensador neo-kantiano), ${ }^{29}$ ele sem dúvida reprova a estreiteza acadêmica, a ênfase erudita na epistemologia e

25 Cf. Beiser, 2015, pp. 282-298.

26 Nietzsche está bem ciente desse fato: "gradualmente, algumas esferas de atuação da filosofia caem nas mãos da ciência” (Nachlass/FP 1872, 19[62], KSA 7.439). Cf. também Nachlass/FP 1872, $19[28]$, KSA 7.425.

27 Cf. Beiser, 2015, pp. 288-89.

28 Cf. Beiser, 2015, pp. 293-97. Beiser mostra que a maioria dos neo-kantianos tentou simplesmente reformular a estratégia de Kant com vistas a uma fundamentação racional da ética, separando completamente o âmbito da investigação teórico-científica da esfera consoante ao valor ético.

29 Cf. carta ${ }^{\circ} 517$ a Carl von Gersdorff, do fim de agosto 1866, KSB 2.159 e carta n ${ }^{\circ} 526$ a Hermann Mushacke, de novembro de 1866, KSB 2.180. Como veremos, o jovem Nietzsche é partidário da estrita limitação do conhecimento, defendida por Lange, ao modo como as coisas são experimentadas por nosso aparato cognitivo, bem como de sua noção relativa ao ponto de vista do ideal, isto é, o ponto de vista moral e estético de que precisamos adotar enquanto suplemento ao ponto de vista científico.

130 | Cad. Nietzsche, Guarulhos/Porto Seguro, v.40, n.3, p. 115-170, setembro/dezembro, 2019. 
no criticismo de outros neo-kantianos, bem como sua falta de atenção em relação à ética.

De fato, na terceira Consideração extemporânea, Nietzsche acusa os filósofos acadêmicos de se preocuparem tão somente com "problemas do conhecimento", ignorando os mais urgentes problemas da existência, tais como, por exemplo, o que diz respeito ao próprio sofrimento humano (Cf. SE/Co. Ext. III 6, KSA 1.383). Tais estudiosos, argumenta ele, são em sua maioria incapazes de compreender e avaliar aquilo que é raro, grande e incomum, quer dizer, importante e essencial (Cf. SE/Co. Ext. III 6, KSA 1.383); "fracassam em perceber os problemas primários da vida, sendo que, por isso mesmo, dedicam-se aos problemas mais ínfimos, isto é, em todos os assuntos relevantes, eles não têm necessidade da verdade" (Nachlass/FP 1873, 29[10], KSA 7.627). Nietzsche considera sua erudição como uma "abstração inumana" que despreza por complete as questões morais fundamentais, ou, quando não, na melhor das hipóteses, trata-as como "meras formalidades" (Cf. SE/Co. Ext. III 2, KSA 1.341), dedicando-se a uma crítica infrutífera "de palavras sobre palavras" (Cf. SE/Co. Ext. III 8, KSA 1.411). É nisso que reside, para Nietzsche, a diferença entre a prática acadêmica de filosofia e a genuína prática filosófica (Cf. também Nachlass/FP 1872, 19[23], KSA 7.423). A seu ver, os professores de filosofia não estão conscientizados dos alvos da educação e da cultura (Cf. SE/Co. Ext. III 6, KSA 1.383); não cultivam nem a si mesmos nem seus leitores, e muito menos a inteira humanidade. ${ }^{30}$ Não praticam a filosofia, por exemplo, como um modo de vida, ${ }^{31}$ de sorte que,

30 Além disso, Nietzsche observa que a erudição acadêmica alemã se acha governada e submetida à autoridade do poder e dos interesses da universidade, do Estado, de pessoas financeiramente bemsucedidas, da opinião pública e, em certa medida, inclusive da moralidade e religião tradicionais. Também por essa razão, diz ele, a filosofia acadêmica é incapaz de reconhecer os problemas mais prementes.

31 Cf. SE/Co. Ext. III 3, KSA1.350. Em contrapartida, como veremos, Nietzsche observa que a vida de tais estudiosos não é afetada por sua profissão intelectual.

Cad. Nietzsche, Guarulhos/Porto Seguro, v.40, n.3, p. 115-170, setembro/dezembro, 2019. | 131 
Serini, L.

focando exclusivamente no "conhecimento puro", tampouco têm algum interesse pela sabedoria (Cf. SE/Co. Ext. III 6, KSA 1.383; SE/Co. Ext. III 8, KSA 1.411).

\section{O problema do ceticismo em Schopenhauer como educador.}

Nessa parte do artigo, analiso atentamente as declarações de Nietzsche sobre o ceticismo em Schopenhauer como educador, visando a reconstruir seu argumento no contexto de suas principais preocupações em tal ensaio. Tal como se tornará patente, ele aborda o problema do ceticismo em relação ao problema da educação, à sua concepção de filósofo e até mesmo em referência à sua crítica à filosofia acadêmica. Na terceira Consideração extemporânea, Nietzsche não está tão interessado na epistemologia, mas, antes do mais, na influência mais ampla do ceticismo sobre a vida humana, mais especificamente sobre os pensadores e, em termos potenciais, sobre a inteira cultura de sua época.

Em SE/Co. Etx. III §3, Nietzsche identifica três perigos que teriam ameaçado Schopenhauer tanto como filósofo quanto como ser humano, a saber: isolamento, desespero da verdade e enrijecimento moral ou intelectual. Tais perigos, sob a ótica nietzschiana, precisam ser examinados, porque, de uma maneira ou de outra, eles ainda nos ameaçam, sobretudo àqueles indivíduos que querem esforçar-se para cultivar a si mesmos (Cf. SE/Co. Ext. III 3, KSA1.350). Assim, fazendo coro com o propósito integral do ensaio, Nietzsche considera o modo com que Schopenhauer enfrenta esses três perigos constitutivos como sendo exemplar e educativo, ilustrando como conduzir uma genuína vida filosófica. Introduz, então, o tópico do ceticismo no contexto consoante ao segundo perigo. Tal ameaça, escreve Nietzsche, é chamada de "desespero da verdade" e "acompanha todo pensador cujo ponto de partida é a filosofia kantiana, supondo que, em seu sofrimento e desejo, ele seja um ser humano forte e completo, e não 
apenas uma máquina ruidosa que cogita e calcula (SE/Co. Ext. III 3, KSA 1.355)". Aquilo que Nietzsche chama de "desespero da verdade", tal como mencionei na introdução, acha-se umbilicalmente ligado ao ceticismo. A seu ver, também o ceticismo tem a ver com Kant e inclusive, como veremos rapidamente, com a crítica aos filósofos acadêmicos (máquinas pensantes):

assim que Kant começar a ter um efeito popular, então nos conscientizaremos disso sob a forma de um ceticismo e relativismo corrosivo e desintegrador. $\mathrm{E}$ somente os espíritos mais ativos e nobres, aqueles que jamais suportariam viver num estado de dúvida, experimentariam um abalo e um desespero de toda verdade tal como aqueles experimentados, por exemplo, por Heinrich von Kleist, como sendo um efeito da filosofia kantiana (SE/Co. Ext. III 3, KSA 1.355).

Como fica indicado nessa passagem, Nietzsche declara que a filosofia de Kant, de certo modo, poderá conduzir a uma forma de ceticismo e relativismo que, corroendo nossas seguranças intelectuais, morais e existenciais, poderia levar pensadores específicos (pressupondo que eles também sejam seres humanos completos) a um estado de desespero, podendo até mesmo representar - caso Kant tenha um impacto de longo alcance - uma ameaça a inteira cultura de sua época. Desespero da verdade é, pois, uma maneira de experimentar a consequência cética (e relativista) do kantismo. ${ }^{32}$ Nos escritos de juventude, Nietzsche também associa uma experiência análoga de desespero a formas de ceticismo e relativismo derivadas de outros tipos de investigação, particularmente da historiografia científica e, em linhas mais gerais, de qualquer crítica radical do conhecimento. Tal como sublinhou Andreas Sommer, "em suas primeiras reflexões filosóficas, Nietzsche tem plena consciência de que uma crítica fundamental do conhecimento tem consequências céticas (...) destruindo todas as espécies de seguranças culturais e

32 Retornarei à relação precisa entre ceticismo e relativismo na terceira parte deste artigo.

Cad. Nietzsche, Guarulhos/Porto Seguro, v.40, n.3, p. 115-170, setembro/dezembro, 2019. | 133 
Serini, L.

intelectuais. ${ }^{\text {"33 }}$ Isso pode ser observado, por exemplo, em HL/Co. Ext. II, onde Nietzsche destaca o resultado cético e relativista decorrente de um excesso de conhecimento histórico em jovens intelectuais, bem como na cultura alemã em geral. ${ }^{34}$ Em Schopenhauer como educador, ao resumir o perigo do desespero relativamente à verdade, Nietzsche ainda caracteriza essa experiência da seguinte maneira: é fácil aos indivíduos naturalmente dotados de perspicácia, que "cresceram acostumados a procurar o pró e o contra nas coisas (...) ficarem confusos em relação à própria verdade, de sorte que precisam viver sem coragem e confiança, negando, duvidando, exasperando, insatisfeitos numa esperança sem convicção e num desapontamento antecipado" (SE/Co. Ext. III 3, KSA 1.360). Tal como veremos, no entanto, a experiência desesperada do ceticismo e relativismo trazido pela filosofia kantiana possui suas próprias características distintivas.

Nietzsche cita o exemplo de Kleist, um conhecido poeta alemão e dramaturgo que, em 1801, sofrera uma profunda crise por conta da leitura da Crítica da razão pura, no intuito de ilustrar como a forma destrutiva de ceticismo e relativismo causada pela filosofia kantiana poderia ser vivenciada como desespero da verdade. ${ }^{35}$ Nietzsche cita diretamente a famosa carta de Kleist à sua noiva, na qual confessa sua reação desesperada a Kant:

33 Sommer, 2018, p. 445.

34 Cf. HL/Co. Ext. II 7, KSA 1.295; HL/Co. Ext. II 8, KSA 1.302 e HL/Co. Ext. II 10, KSA 1.324. Vale comparar tais seções com DS/Co. Ext. I 3, KSA 1.159 e SE/Co. Ext. III 8, KSA 1.411. Em HL/ Co. Ext. II, Nietzsche argumenta que uma educação focada exclusivamente no ensino de história - e história da filosofia - engendra uma forma de ceticismo sobre "todos os costumes e conceitos" (HL/ Co. Ext. II 7, KSA 1.299), expondo a relatividade cultural de todas as práticas e ideias. Essa forma de ceticismo, observa Nietzsche, gerando confusão acerca das opiniões, poderia desencorajar jovens pensadores a ter opiniões próprias ( $c f$. SE/Co. Ext. III 8, KSA 1.411), levando-os inclusive a um estado de "apatia melancólica" (HL/Co. Ext. II 7, KSA 1.300), assim como a uma inatividade intelectual e prática. "Essa infinita desesperança do ceticismo [hoffnungslose skeptische Unendlichkeit]" (HL/Co. Ext. II 10, KSA 1.324), tal como a denomina o jovem Nietzsche, também poderia ter consequências nocivas à inteira cultura de sua época, conduzindo a uma estagnação cultural e obstaculizando a criatividade tanto no agir como no pensar.

35 Sobre a crise kantiana de Kleist, $c f$. Scott, 1947, pp. 474-484 e Mehigan, 2011, pp.15-32.

134 | Cad. Nietzsche, Guarulhos/Porto Seguro, v.40, n.3, p. 115-170, setembro/dezembro, 2019. 
"Há pouco tempo," escreve ele [Kleist], à sua maneira envolvente, "entrei em contato com a filosofia de Kant - e agora preciso comungar contigo uma de suas ideias, já que não ouso temer que ela irá te sacudir tão profunda e dolorosamente quanto me sacudiu. Não podemos decidir se aquilo que denominamos verdade é realmente verdade ou se apenas assim se nos parece. Se for mesmo este último caso, então a verdade que coletamos aqui já não é nada após a nossa morte, sendo que todos os nossos esforços para obter uma posse capaz de nos acompanhar até o túmulo são em vão. Se a ponta desse pensamento não perfura seu coração, por favor não deboche, sorrindo, de alguém que se sente profundamente ferido por ele no que há de mais intimamente sagrado em seu ser. Meu único e supremo propósito desapareceu, e não possuo mais nenhum outro" (SE/Co. Ext. III 3, KSA $1.355)$.

Kleist, e, por meio dele, o próprio Nietzsche, refere-se inequivocamente ao idealismo transcendental kantiano, ou, mais precisamente, à sua distinção entre as aparências e as coisas em si mesmas, bem como à sua limitação do conhecimento às primeiras. Para Kleist e Nietzsche, a filosofia kantiana demonstra que não nos é dado obter conhecimento de uma verdade absoluta apta a responder às derradeiras questões relativas à moral, religião e aspirações existenciais. Tal como escreverá Nietzsche num apontamento não publicado de 1885, o desespero de Kleist é, com efeito, "um suspiro sobre o incognoscível. (Nachlass/FP 1885, 34[126], KSA 11.463)". Pretendo enfatizar a interpretação nietzschiana do idealismo transcendental de Kant como uma forma de ceticismo e relativismo na terceira parte do presente artigo. Por ora, tratarei de dar continuidade à minha exegese de SE/Co. Ext. III §3.

O exemplo de Kleist tem o objetivo de ilustrar como o ceticismo e o relativismo causados pela filosofia kantiana poderiam ser vivenciados enquanto desespero da verdade. Nietzsche apresenta isso como um perigo que ameaça o desenvolvimento do ser humano integral, assim como pensadores tais como Kleist e Schopenhauer. O ceticismo (experimentado) como desespero da verdade acha-se, desse modo, relacionado ao problema da educação e, em especial, à tentativa

Cad. Nietzsche, Guarulhos/Porto Seguro, v.40, n.3, p. 115-170, setembro/dezembro, 2019. | 135 
Serini, L.

de cultivar a si mesmo por meio da prática da filosofia enquanto modo de vida. $\mathrm{O}$ desespero da verdade é uma aflição filosófica que perturba profundamente tanto a mente quanto os sentimentos dos genuínos pensadores (Cf. Nachlass/FP 1873, 30[15], KSA 7.737-38). Tal como será revelado no Prólogo à Humano, demasiado humano II, de 1886, o próprio Nietzsche encontrava-se exposto a esses perigos: “ (...) na terceira Consideração extemporânea (...) eu já me encontrava, da minha própria parte, em meio ao ceticismo e à dissolução moral, quer dizer, isso tanto na crítica quanto no aprofundamento de todo pessimismo prévio - e já não acreditava 'em mais nada', como o povo diz, e nem mesmo no próprio Schopenhauer" (MAII/HH II, Prólogo 1, KSA 2.370). Aqui, é importante enfatizar duas coisas: em primeiro lugar, Nietzsche caracteriza esse ceticismo como moral e, em segundo, reafirma que em 1874 ele já não acreditava em Schopenhauer - sobretudo, tal como vimos, em sua metafísica da Vontade. Contudo, em Schopenhauer como educador, Nietzsche continua a afirmar que, embora Kleist tivesse demonstrado sua inadequação diante desse perigo, Schopenhauer foi exitoso ao superálo filosófica e pessoalmente, chegando inclusive a atingir uma "alegria encorajadora" capaz de mover e animar verdadeiramente os leitores, a despeito da seriedade do problema em jogo (Cf. SE/Co. Ext. III 2, KSA 1.341).

O ceticismo também se relaciona com a concepção nietzschiana de filósofo. Nietzsche mantém Schopenhauer como o exemplar do verdadeiro filósofo, aquele que desativa o efeito cético e relativista da filosofia kantiana, superando o perigo do desespero pela verdade. Depois de Kant, afirma Nietzsche, Schopenhauer representa o guia que "nos conduz para fora da caverna do descontentamento cético ou da renúncia crítica rumo às alturas da contemplação trágica. ${ }^{936}$ Do

36 SE/Co. Ext. III 3, KSA 1.356. A compreensão nietzschiana da resposta exemplar de Schopenhauer ao aludido perigo e, em termos mais gerais, do papel do filósofo em relação ao ceticismo será o tema da terceira parte do presente artigo.

136 | Cad. Nietzsche, Guarulhos/Porto Seguro, v.40, n.3, p. 115-170, setembro/dezembro, 2019. 
ponto de vista nietzschiano, o exemplo de Schopenhauer nos fornece uma terapia pessoal contra o desespero cético e indica uma nova direção à filosofia, assim como, potencialmente, à inteira cultura $(C f$. SE/Co. Ext. III 3, KSA 1.350). Dedicarei a quarta parte do presente artigo à discussão de Nietzsche acerca da resposta exemplar de Schopenhauer ao ceticismo. Por ora, basta dizer que, em oposição a Kant e, em especial, aos filósofos acadêmicos, Schopenhauer empenha-se em elaborar uma sabedoria filosófica que oferece uma orientação sobre como viver. Tal como Nietzsche complementa, nos póstumos de 1873, a crise de Kleist é o sub-produto da ineficácia de "um excesso de pensamento [crítico]" (Nachlass/FP 1873, 29[230], KSA 7.723; Nachlass/FP 1873, 30[15], KSA 7.737-38). Nietzsche contrasta a "simplicidade dos antigos", que praticavam filosofia como um modo de vida, ${ }^{37}$ com "os efeitos da filosofia kantiana" em pensadores tais como Kleist: "deve-se ter uma filosofia apenas até o ponto em que seja possível viver de acordo com tal filosofia: para que tudo não se converta em meras palavras" (Nachlass/FP 1873, 30[17], KSA 7.738; Cf. SE/Co. Ext. III 3, KSA 1.350 e SE/Co. Ext. III 8, KSA 1.411). Num outro fragmento póstumo, Nietzsche de fato sugere que Kleist cai num estado de desespero, porque "Ihe faltava Schopenhauer" (Nachlass/FP 1873, 29[204], KSA 7.712), quer dizer, faltava-lhe uma filosofia capaz de organizar o conhecimento sob a forma de sabedoria, de sorte a lhe oferecer uma orientação à vida.

Embora o desespero da verdade seja apresentado como um perigo a pensadores específicos - e, potencialmente, a maioria das pessoas (Cf. SE/Co. Ext. III 4, KSA 1.363) -, Nietzsche considera essa experiência desesperadora como sendo um "modo natural" de

37 Cf. HL/Co. Ext. II 10, KSA 1.324; SE/Co. Ext. III 3, KSA 1.350 e SE/Co. Ext. III 8, KSA 1.411. Que se compare ainda com o seguinte fragmento: "As máximas dos antigos sobre a moralidade sempre derivaram dos exemplos vivos de pessoas que haviam vivido de acordo com tais máximas. Não compreendo as coisas estranhas e distantes de que falam os moralistas modernos: concebem o ser humano como uma criatura miraculosamente espiritual; parecem considerar impróprio tratar o ser humano à maneira despudoradamente antiga e falar de suas baixas, porém necessárias carências" (Nachlass/FP 1873, 31[4], KSA 7.749).

Cad. Nietzsche, Guarulhos/Porto Seguro, v.40, n.3, p. 115-170, setembro/dezembro, 2019. | 137 
Serini, L.

sentir em reação à filosofia kantiana ( $c f$. SE/Co. Ext. III 3, KSA 1.350). Com efeito, ao falar de pensadores que, tal como Kleist, cairiam no desespero, Nietzsche considera-os "os mais ativos e nobres espíritos", sugerindo que deveria ser natural medir a filosofia em relação à própria vida, isto é, muito além de um interesse exclusivamente teórico e acadêmico. Mas esse sentimento é natural sobretudo noutro sentido: como veremos, Nietzsche pressupõe que tais pensadores, bem como todo nós, "jamais suportariam viver num estado de dúvida" por conta de uma profunda necessidade de certeza e segurança, a qual, nos textos de juventude, ele atribui a todos os seres humanos.

Isso nos leva à relação entre o ceticismo e a crítica nietzschiana à filosofia acadêmica. Bem ao estilo das Considerações extemporâneas, Nietzsche observa polemicamente que, apesar de a obra de Kant ser tida como "desencadeadora de uma revolução em todos os campos da investigação intelectual" (Cf, também SE/Co. Ext. III 7, KSA 1.404), ainda não há sinais de uma transformação radical naqueles "seres humanos que, antes de mais nada, teriam de ter sido, eles próprios, revolucionados" (SE/Co. Ext. III 3, KSA 1.355). Nietzsche refere-se, aqui, claramente, àqueles estudiosos kantianos que, como vimos, praticam filosofia meramente como uma disciplina teórica (na maioria das vezes, em chave epistemológica), impessoal e acadêmica. A filosofia kantiana, comenta Nietzsche, até agora transformou apenas alguns poucos pensadores genuínos tais como Kleist, os quais, ao contrário dos filósofos acadêmicos, procuram o conhecimento em relação às suas vidas, seus sofrimentos e desejos. Para Nietzsche, em vez disso, os eruditos são caracterizados pela "pobreza de sentimentos e aridez": não têm sequer "pressentimento do sofrimento que acompanha indissociavelmente certos tipos de conhecimento" (SE/Co. Ext. III 6, KSA 1.396).

Paralelamente ao perigo do desespero da verdade, Nietzsche também reconhece o risco de ser "emaranhado numa teia de conceitualizações escolásticas” (SE/Co. Ext. III 3, KSA 1.357), 
sobretudo quando se toma Kant como um exemplo (Cf. SE/Co. Ext. III 3, KSA 1.350; SE/Co. Ext. III 7, KSA 1.404). Não é difícil a um pensador, constata Nietzsche, "dando rédea livre ao seu talento, perecer enquanto ser humano e viver meramente uma existência fantasmagórica no reino da "pura ciência."” (SE/Co. Ext. III 3, KSA 1.360). Assim, sob a ótica de Nietzsche, além da experiência do desespero, há ainda um outro perigo envolvido na filosofia kantiana: lidar com o ceticismo e o relativismo causado por Kant tão somente como se tratasse de problemas epistêmicos escolásticos, apartados dos problemas da vida, educação e cultura. ${ }^{38}$ A esse respeito, Nietzsche acrescenta no $§ 8$ de SE/Co. Ext. III que:

Recentemente, eles [os filósofos acadêmicos] começaram a se comprazer em afirmar que, de fato, são apenas os guardas de fronteira e vigias das disciplinas científicas [Wissenschaften]; para esse fim, estão particularmente bem servidos pela doutrina kantiana, a qual tencionam transformar num ceticismo inerte ao qual, em breve, ninguém mais irá prestar atenção (SE/ Co. Ext. III 8, KSA 1.419).

Preocupados exclusivamente com a epistemologia e, mais precisamente, com o exame crítico das ciências, os filósofos universitários, para Nietzsche, fracassam em reconhecer - e experimentar pessoalmente - o perigo da filosofia kantiana; lançam mão do criticismo de Kant para sustentar um ceticismo inerte de acordo com o qual é "mais filosófico não saber nada do que aprender algo" (SE/Co. Ext. III 8, KSA 1.419). Nietzsche acusa os eruditos kantianos de terem negligenciado gravemente uma série de importantes tarefas filosóficas concernentes à educação. Caracteriza seu ceticismo como inerte tanto no sentido de sua ociosidade quanto pelo fato de ele ser inútil. Ele é ocioso, porque faltam a tais filósofos acadêmicos a disposição e a coragem para tentar levar a efeito novos

38 Esse ponto veio à tona numa conversa que entabulei com o professor Keith Ansell-Pearson, meu orientador na Universidade de Warwick.

Cad. Nietzsche, Guarulhos/Porto Seguro, v.40, n.3, p. 115-170, setembro/dezembro, 2019. | 139 
Serini, L.

e grandes empreendimentos filosóficos (Cf. SE/Co. Ext. III 8, KSA 1.411), e sobretudo para renovar a reflexão sobre questões morais e para trabalhar na criação de uma nova moralidade. Nietzsche ataca os eruditos kantianos, por exemplo, por estes não se interessarem absolutamente pela sabedoria, permanecendo indiferentes à tarefa da filosofia enquanto terapia cultural: eles "jamais são corajosos como Lucrécio e indignados com as aflições que oprimem os seres humanos" (SE/Co. Ext. III 8, KSA 1.420).

O ceticismo defendido pelos filósofos acadêmicos também é inútil e inclusive prejudicial a certos indivíduos, e, quiçá, à inteira cultura da época. Tal como Nietzsche os concebe, os professores de filosofia, em seus propósitos meramente críticos, "estão dissecando e dissolvendo todas as crenças firmes" (SE/Co. Ext. III 4, KSA 1.366), "pouco importa quão veneráveis" ou quão valiosas à vida (Cf. SE/Co. Ext. III 6, KSA 1.383), mas sem proporcionar nenhum outro ideal ético capaz de oferecer uma orientação sobre como viver (Cf. também SE/Co. Ext. III 2, KSA 1.341; SE/Co. Ext. III 6, KSA 1.383). A polêmica nietzschiana conta enfatizar o fato de que a investigação científica e acadêmica, ao largo de uma preocupação construtiva sobre os problemas da vida, educação e cultura, "produz um desassossego, uma confusão nas almas modernas, condenandoos a ser infrutíferos e sem alegria" (SE/Co. Ext. III 2, KSA 1.345). Todavia, ao menos em 1874, Nietzsche parece estar convencido de que, por enquanto, Kant ainda não surtiu um efeito popular, tendo afetado significantemente apenas algumas pessoas tais como Kleist. Essa é uma das razões por que, segundo Nietzsche, seu respectivo discurso acerca de Kant manteve-se, em grande parte, confinado nas universidades, sendo que, em breve, ninguém mais irá dar atenção ao inerte ceticismo por ele incitado. ${ }^{39}$

39 Em vez disso, em Humano, demasiado humano (1878), Nietzsche irá assumir uma visão completamente diferente: “(...) é bastante possível que, quanto a isso, a humanidade em geral e como um todo se torne, algum dia, cética; a ser assim, a questão então será: como a sociedade humana irá adquirir forma sob o influxo de uma tal convicção?" (MA I/HH I 21, KSA 2.42).

140 | Cad. Nietzsche, Guarulhos/Porto Seguro, v.40, n.3, p. 115-170, setembro/dezembro, 2019. 


\section{Ceticismo (e relativismo) como consequências destrutivas da filosofia kantiana.}

Até agora, mostrei de que modo a discussão de Nietzsche sobre o ceticismo se relaciona com suas principais preocupações em Schopenhauer como educador. Nesta seção do artigo tratarei de focalizar o quadro kantiano, ou, mais precisamente, pós-kantiano relativo à problemática cética presente em tal ensaio, bem como nos escritos de juventude. No texto, Nietzsche não adentra numa análise filosófica detalhada, para então esclarecer sua alegação de que a filosofia kantiana poderia conduzir ao ceticismo e ao relativismo. Creio que isso se deve a duas razões fundamentais. Em primeiro lugar, tal como enfatizei, na terceira Consideração extemporânea ele não está primordialmente preocupado com epistemologia e metafísica, senão que com o efeito da teoria sobre a vida humana. Em segundo lugar, sua menção a Kant teria sido imediatamente compreendida pelo leitor da época, haja vista que, na segunda metade do século XIX, boa parte da filosofia alemã partia de premissas kantianas. A alusão de Nietzsche à revolução filosófica empreendida por Kant e sua citação da carta de Kleist (SE/Co. Ext. III 3, KSA 1.350) apontam, de fato, para o idealismo transcendental, uma das teorias kantianas mais famosas e debatidas. Não estou muito interessado, aqui, em saber se Nietzsche compreendeu corretamente Kant e tampouco nas complexidades de sua recepção inicial da filosofia kantiana. ${ }^{40}$ Tenciono, antes do mais, especificar os pressupostos teóricos derivados da filosofia kantiana que subjazem à concepção

40 Há um amplo e crescente material bibliográfico consagrado à investigação do engajamento de Nietzsche com a filosofia kantiana e o próprio Kant, mas também de seu comprometimento com Schopenhauer e Lange. Sobre a relação Nietzsche e Kant, cf. Hill, 2003 e Brusotti/Siemens, 2017. Sobre um relato das semelhanças e dessemelhanças entre as leituras kantianas de Schopenhauer e Lange - bem como de Kuno Fischer -, cf. em especial Hill, 2003, pp.13-19 e Constâncio, 2017, pp. 103-138. Acerca de Nietzsche e Schopenhauer, $c f$. Janaway, 1998, pp. 13-36. A propósito de Nietzsche e Lange, $c f$. Stack, 1983.

Cad. Nietzsche, Guarulhos/Porto Seguro, v.40, n.3, p. 115-170, setembro/dezembro, 2019. | 141 
Serini, L.

nietzschiana de ceticismo presente em SE/Co. Ext. III §3. Tal como tenho argumentado, Nietzsche reputa-os verdadeiros, porém mortais.

Devo iniciar com uma breve consideração acerca daquilo que Nietzsche acredita ser verdadeiro na filosofia kantiana. Num estudo recente, João Constâncio resumiu de modo assaz útil o pós-kantismo de Nietzsche em cinco pontos centrais:

1. "as categorias básicas do mundo tal como este se nos aparece (isto é, do 'phenomena') pertencem ao nosso aparato cognitivo, e não à coisa em-si;",41

2. "Nietzsche sustenta a tese de que nossas categorizações prévias, quer dizer, os conceitos e juízos básicos que não retiramos de nossa experiência (ou da natureza), senão que 'colocamos' em nossa experiência (ou 'prescrevemos à natureza'), estruturam e dão forma ao nosso mundo:" $" 42$

3. “não há conhecimento das 'coisas em si mesmas' ou da 'coisa em-si'. Esse é o posicionamento de Nietzsche no ensaio póstumo Sobre verdade e mentira no sentido extra-moral, mas também em Humano, demasiado humano; ${ }^{43}$

4. "os sujeitos humanos não têm acesso à verdade metafísica, ou, então, que não há verdade alguma, se por 'verdade' se entende 'verdade metafísica', 'verdade absoluta' ou uma derradeira

\footnotetext{
41 Constâncio, 2017, p. 104. Com acerto, Constâncio enfatizou que, mediante a leitura de Schopenhauer, Fischer e, em especial, Lange, Nietzsche tende a naturalizar as formas transcendentais da sensibilidade e do entendimento de Kant, concebendo-as sobretudo como a organização fisiológica do aparato cognitivo humano ( $c f$. Constâncio, 2017, p. 104 e p.111). Cf., por exemplo, o seguinte fragmento póstumo: "as formas do intelecto emergiram muito gradualmente a partir da matéria (...) de onde mais poderia possivelmente ter surgido um tal aparato, que inventa algo novo! (Nachlass/FP 1872, 19[153], KSA 7.467). Além disso, ao contrário de Kant, para Nietzsche não apenas as formas de nosso entendimento e nossa linguagem possuem sua origem nas funções e mecanismos do organismo humano, senão que elas também constituem um produto do desenvolvimento histórico - e, portanto, cultural. A esse respeito, $c f$. Zavatta, 2017, pp. 45-70.
}

42 Constâncio, 2017, p. 10, p.104.

43 Constâncio, 2017, p.104.

142 | Cad. Nietzsche, Guarulhos/Porto Seguro, v.40, n.3, p. 115-170, setembro/dezembro, 2019. 
verdade ontológica - ' $a$ Verdade’ sobre aquilo que, por fim, seria a realidade;" $" 44$

5. “a filosofia teórica de Kant alterou para sempre a filosofia, ao mostrar que a metafísica [tradicional] é impossível." ${ }^{45}$

Tal como ficará patente, o ceticismo e o relativismo são consequências diretas da terceira (epistêmica) e quarta (metafísica) teses - e, em certa medida, igualmente da quinta. Todavia, no que tange à terceira tese, a metafísica, especificaria apenas que, no período de juventude, Nietzsche ainda retém de algum modo, sob a influência de Schopenhauer, a noção de coisa em-si com algo existente: mas, à diferença de Schopenhauer, considera a coisa em-si como algo estritamente incognoscível, avessa a qualquer tentativa de determinála mediante conceitualização ou por intermédio da linguagem. ${ }^{46}$ Em vez de afirmar que não há uma verdade metafísica, o jovem Nietzsche sustenta uma posição mais agnóstica, ${ }^{47}$ de acordo com a qual a coisa em-si kantiana seria "somente um X, a nós inacessível e indefinível." 48 Assim, assevera ele, a única declaração metafísica que se nos seria permitido fazer a respeito da coisa em-si é a de que, em nos sendo indeterminável, ela permanece indeterminada. ${ }^{49}$

44 Constâncio, 2017, p. 105.

45 Constâncio, 2017, p. 106.

46 "Não podemos falar nada sobre a coisa em-si, porque, com isso, retiramos sob os nossos próprios pés o ponto de vista daquele que conhece, isto é, que dá a medida." (Nachlass/FP 1872, 19[156], KSA 7.468).

47 Nisso, Nietzsche aproxima-se da posição defendida por Kant na Crítica da razão pura, conforme a qual só nos é facultado falar da coisa em-si num sentido negativo, como um conceito-limite. $(C f$. Kant,1989, B 310-B 311).

48 WL/VM 1, KSA 1.880 e KSA 1.879; e $c f$. também Nietzsche, 2009, [“Zu Schopenhauer”], pp.3-5 (Nachlass/FP 1867-1868, 57 [55], KGW I, 4.418-430).

$49 \mathrm{Em}$ A filosofia na era trágica dos gregos (1873), Nietzsche curiosamente compara a coisa em-si kantiana ao apeiron de Anaximandro: "Essa última unidade naquele 'indeterminado', ventre materno de todas as coisas, só pode, com efeito, ser descrita negativamente pelo ser humano, quer dizer, como algo a que não pode ser concedido nenhum predicado advindo do mundo existente do vir-a-ser e que, devido a isso, poderia valer como algo semelhante à 'coisa em-si' kantiana” (PHG/FT 4, KSA 1.819).

Cad. Nietzsche, Guarulhos/Porto Seguro, v.40, n.3, p. 115-170, setembro/dezembro, 2019. | 143 
Serini, L.

É importante notar que, para Kant, tais teses não acarretam uma forma de ceticismo ou relativismo; ao contrário, ele visava à sua filosofia crítica como uma resposta ao ceticismo, no intuito de reformar a metafísica tanto no âmbito teórico quanto na esfera prática. ${ }^{50} \mathrm{Na}$ Crítica da razão pura, Kant argumenta que só nos é dado obter conhecimento das coisas tal como estas se nos aparecem, quer dizer, de objetos que podemos experimentar no mundo empírico; ao passo que nos é impossível conhecer as coisas em si mesmas, isto é, objetos supra-sensíveis tais como, por exemplo, Deus, a alma imortal e a vontade livre, os quais nos seria facultado pensar a respeito, mas que transcendem nossa experiência possível. Segundo Kant, nos limites da experiência humana possível, teríamos um acesso epistêmico direto ao mundo empírico, sendo-nos possível adquirir um conhecimento teórico e científico dele (realismo empírico). Por outro lado, sustenta que não temos acesso às coisas em si mesmas e que, portanto, nos é impossível adquirir um conhecimento teórico-científico de objetos suprassensíveis. Não podemos saber, por exemplo, que Deus existe, a alma é imortal ou somos livres para agir no mundo. Isso está em plena conformidade com a rejeição kantiana da metafísica tradicional, que tinha a pretensão de lidar teórica e cientificamente com as coisas em si mesmas, especulando, digamos, sobre a existência de Deus, a imortalidade da alma e a liberdade da vontade.

Kant, no entanto, não conta denegar nem a existência das coisas em si mesmas nem sua importância para a vida humana. A seu ver, as ideias de Deus, alma imortal e vontade livre não são meros produtos arbitrários da metafísica tradicional, senão que possuem sua origem na natureza mesma da razão humana. Kant acredita que tais ideias são naturais e constituem exigências inevitáveis relativamente às mais importantes aspirações dos seres humanos. A ser assim, declara ele, não podemos evitar pensá-las, mesmo sem conhecê-las em termos teóricos e científicos. Sob sua ótica, denegar o conhecimento

50 Sobre Kant e o ceticismo, $c f$. em especial Guyer, 2006, pp.8-13; e Forster, 2008.

144 | Cad. Nietzsche, Guarulhos/Porto Seguro, v.40, n.3, p. 115-170, setembro/dezembro, 2019. 
das coisas em si mesmas não implica que tenhamos de renunciar a elas; estas passam a adquirir, ao contrário, o mais importante significado noutra área da racionalidade humana, a saber, no domínio da razão prática. ${ }^{51}$ Desse modo, já que nos falta um conhecimento das coisas em si mesmas, não nos sendo dado nem provar nem refutar nossas afirmações a seu respeito, Kant conclui que podemos e devemos acreditar nelas a fim de dar cumprimento às nossas esperanças morais e existenciais. Na filosofia kantiana, portanto, Deus, imortalidade e liberdade permanecem fontes fundamentais de valor moral e existencial. Nesse trilho, ao separar um âmbito teórico de uma esfera prática, Kant tencionava reconciliar o conhecimento científico com a moralidade e religião tradicionais.

A afirmação de Nietzsche de que a filosofia kantiana poderia conduzir a uma forma destrutiva de ceticismo e relativismo devese sobretudo, creio eu, a duas razões interrelacionadas: primeiro, à sua leitura indireta e mediada de Kant, em especial por meio de Schopenhauer e Lange; e, segundo, à sua insatisfação com a própria tentativa kantiana de solucionar o problema do ceticismo principalmente no domínio da ética. ${ }^{52}$ Em relação à primeira razão, Stefano Busellato mostrou com clareza que o jovem Nietzsche adota um posicionamento cético enquanto um resultado de sua peculiar recepção da filosofia kantiana por meio de Schopenhauer e Lange, terminando por considerar apenas a pars destruens da Crítica da razão pura - aquela denegação do conhecimento das coisas em si mesmas. ${ }^{53}$ Para Busellato, as distintas leituras de Kant empreendidas por Schopenhauer e Lange entram em conflito no pensamento nietzschiano de juventude, resultando numa posição cética que, de algum modo, é

51 Kant também declara que as ideias da razão, que podem ser por nós pensadas, mas não conhecidas, possuem ainda uma grande importância enquanto princípios regulativos, funcionando como coordenadas assintóticas que orientam nossas investigações teóricas e científicas.

52 Dito isso, deveria estar claro, a essa altura, que aquilo que está em jogo para o jovem Nietzsche não é a exegese erudita de Kant, mas, mais fundamentalmente, os problemas da vida, educação e cultura.

53 Cf. Busellato, 2012, pp.125-201.

Cad. Nietzsche, Guarulhos/Porto Seguro, v.40, n.3, p. 115-170, setembro/dezembro, 2019. | 145 
estranha tanto a Schopenhauer quanto a Lange, assim como a Kant. Ao seguir Schopenhauer, Nietzsche tem a propensão de reduzir Kant à distinção entre phenomenon e coisa em-si, entre ilusão e verdade. ${ }^{54}$ Ao seguir Lange, Nietzsche permanece completamente comprometido com a limitação kantiana do conhecimento aos fenômenos. Dessa forma, como vimos, por meio de Lange, Nietzsche rejeita a tentativa metafísica schopenhaueriana de determinar a coisa em-si como Vontade ${ }^{55}$ enquanto que, por intermédio de Schopenhauer, ele tende a relegar o conhecimento teórico e científico à mera aparência, ou, por vezes, à ilusão, junto a algo que, de qualquer modo, perde a verdadeira essência das coisas. ${ }^{56} \mathrm{O}$ efeito combinado dessas interpretações

54 Embora nos fragmentos póstumos Nietzsche pareça estar no mínimo consciente de que "confundimos com muita facilidade a coisa em-si de Kant com a verdadeira essência das coisas dos budistas [leia-se Schopenhauer]; quer dizer, a realidade mostra uma completa aparência ou uma aparição completamente adequada à verdade" (Nachlass/FP 1872, 19[148], KSA 7.466).

55 Cf. Busellato, 2012, pp. 166-170.

56 Cf. Busellato, 2012, pp. 170-178. Busellato afirma que Nietzsche refutaria, pois, a validade dos juízos sintéticos a priori que, conforme Kant e de acordo com o neo-kantismo de Lange, legitima e assegura a certeza epistêmica das ciências ( $c f$. Busellato, 2012, pp.145-155). De fato, nos póstumos, Nietzsche opõe a filosofia kantiana - a despeito das próprias intenções de Kant - às ciências: "se as ciências estiverem corretas, então já não nos encontramos mais sobre a fundação kantiana; se Kant estiver correto, então as ciências estão incorretas" (Nachlass/FP 1872, 19[125], KSA 1.459). A esse respeito, Kevin R. Hill observou que, "nos apontamentos de juventude, Nietzsche interpreta o idealismo transcendental como uma espécie de ceticismo" (Hill, 2003, p. 25). Todavia, como veremos brevemente, a questão de se o jovem Nietzsche defende o realismo empírico kantiano (de acordo com o qual as ciências teriam um acesso epistêmico a um tipo específico de verdade) tem mais nuances do que aquilo que é dito em Nachlass/FP 1872, 19[125], KSA 1.459. Penso que o posicionamento inicial de Nietzsche a esse propósito deixa-se refletir melhor em WL/VM 1, KSA 1.879-80. Cf., em particular, a discussão de Nietzsche acerca da palavra "aparência": "A palavra 'aparência' contém muitas seduções, razão pela qual eu a evito o tanto quanto possível: pois não é verdade que a essência das coisas aparece no mundo empírico" (WL/VM 1, KSA 1.884). Nietzsche conta enfatizar que o mundo das coisas tal como nós as experimentamos não corresponde à verdadeira essência das coisas, a qual está condenada a nos permanecer incognoscível. Contudo, ele não parece insinuar, com isso, que não podemos ter algum tipo de acesso epistêmico ao mundo empírico. $\mathrm{O}$ próprio Busellato (Busellato, 2012) sugeriu que a ênfase dada por Schopenhauer à distinção entre fenômeno e coisa em-si garante, de alguma maneira, a validade do conhecimento científico no domínio das aparências. Nesse sentido, ainda que as ciências fracassem em penetrar na verdadeira essência das coisas, elas teriam acesso a um tipo de verdade como aparência, quer dizer, a uma verdade para nós, seres humanos. Essa espécie de verdade, como veremos, está relacionada com o problema do relativismo. 
conflitantes, afirma Busellato, faz com que Nietzsche recepcione a filosofia kantiana como uma forma de ceticismo equivalente a um "pessimismo epistêmico", ${ }^{57}$ que denega a possibilidade de se obter qualquer conhecimento seguro - não apenas da coisa em-si. ${ }^{58}$

A explicação de Busellato é, em grande medida, bastante acurada e convincente, mas gostaria de enfatizar algumas nuanças inexploradas do posicionamento cético de Nietzsche. Conto esclarecer, em particular, a relação entre ceticismo e relativismo, que permanece completamente inexplicada em SE/Co. Ext. III §3, tendo sido, com frequência, negligenciada na literatura secundária. Uma breve consideração acerca do problema do relativismo nos permitirá lançar uma maior luz sobre a natureza dos pressupostos epistêmico e metafísico, derivados da filosofia kantiana, que subjazem à concepção nietzschiana de ceticismo em Schopenhauer como educador, bem como nos escritos de juventude. Num artigo recente, Luca Lupo chamou atenção para o fato de que SE/Co. Ext. III §3 continha a única ocorrência do termo "relativismo" (Relativismus) em toda obra de Nietzsche. ${ }^{59}$ De acordo com Lupo, o problema do relativismo (assim como o do ceticismo) na filosofia nietzschiana

57 Busellato, 2012, p.143.

58 Cf. Busellato, 2012, p.155 e 172. Busellato associa esse posicionamento ao ceticismo de Hume (cf. Busellato, 2012, p.147). Ele propõe que, ao refutar a validade dos juízos sintéticos a priori, o ceticismo humiano (conforme o qual não podemos justificar racionalmente, por exemplo, nosso uso da noção de causação) continua, para o jovem Nietzsche, uma posição válida a despeito da tentativa kantiana de refutá-lo ( $c f$. Busellato, 2012, p.153). Dever-se-ia notar, contudo, que o posicionamento cético inicial de Nietzsche não se reduz a Hume. Tal como Constâncio sublinhou, no que concerne à primeira tese, a posição de Nietzsche 'é distintivamente 'kantiana' (e não, digamos, humeana), porque envolve a afirmação de que nosso conhecimento é condicionado por um aparato cognitivo humano (...) e que, de modo ainda mais importante, parte de tal aparato é conceitual - ou, noutros termos, que nem todas nossas categorizações básicas são abstraídas da experiência (isto é, mediante 'associação', 'hábito' etc.)" (Constâncio, 2017, p.104). Ao contrário de Hume, (ao menos) para o jovem Nietzsche, o aparato cognitivo humano informa intuitiva, conceitual e linguisticamente nosso conhecimento do mundo. Acerca disso, $c f$. em particular WL/VM 1, KSA 1.885.

59 Cf. Lupo, 2019. Enquanto Lupo focalizou o vínculo entre o posicionamento relativista inicial de Nietzsche e a filosofia schopenhaueriana, Constâncio, de sua parte, concentrou-se na noção nietzschiana de "verdade relativa", enfatizando sua ligação com Lange ( $c f$. Constâncio, 2017).

Cad. Nietzsche, Guarulhos/Porto Seguro, v.40, n.3, p. 115-170, setembro/dezembro, 2019. | 147 
desenvolve-se no contexto de seu engajamento com o kantismo, e, em especial, com Lange e Schopenhauer. Referindo-se a inúmeras passagens d'A filosofia na era trágica dos gregos, Lupo mostra que o quadro kantiano-schopenhaueriano formado pelo período de juventude do pensamento de Nietzsche termina por conduzi-lo a uma posição relativística conforme a qual só nos é dado obter um acesso epistêmico à "verdade relativa", quer dizer, à verdade condicionada pelo sujeito humano. Nesse sentido, para Lupo, o jovem Nietzsche sustenta que podemos adquirir conhecimento de verdades condicionadas e relativas à maneira que percebemos e conceitualizamos o mundo; ${ }^{60}$ por outro lado, não nos é facultado conhecer a verdade entendida como verdade "absoluta", ${ }^{61}$ quer dizer, uma verdade que exista independentemente da experiência humana. ${ }^{62}$ À luz da concepção nietzschiana de relativismo, espero

60 Sobre um outro exemplo dessa posição, $c f$. "Sobre verdade e mentira no sentido extra-moral". Acerca da relatividade da percepção, $c f$. TL WL/VM 1, KSA 1.884-85; a respeito da parcialidade dos conceitos, $c f$. WL/VM 1, KSA 1.879-80; a propósito da linguagem como uma condição de nossa experiência de mundo, $c f$. WL/VM 1, KSA 1.883.

61 Fazendo coro com Busellato, Lupo (2019) sublinha que, ainda sob a influência de Schopenhauer, Nietzsche considera a verdade absoluta implicitamente como algo existente - ainda que incognoscível (cf. Busellato, 2012, p.127).

62 Cf. Lupo, 2019, pp. 126-128. Tal como argumentou Constâncio, Nietzsche toma de empréstimo a noção de "verdade absoluta" de Lange ( $c f$. Constâncio, 2017, pp.105-106). No que concerne à quarta tese relativa ao pós-kantismo de Nietzsche, Constâncio especifica que “"a verdade relativa' significa, antes de mais nada, a 'verdade para nós', a pluralidade de 'verdades' que podem ser encontradas na investigação científica e, em certa medida, igualmente em nossa vida diária (quando dizemos coisas como, por exemplo, 'está chovendo' ou 'perdi minha passagem')" (Constâncio, 2017, p.105). Constâncio refere-se à seguinte passagem das preleções de Nietzsche sobre os Filósofos pré-platônicos (1869-1872): "O materialismo é uma hipótese válida de relatividade da verdade; assim, 'tudo é falso' foi descoberto para ser uma noção iluminadora à ciência natural. Ainda consideramos, pois, todos os seus resultados como sendo verdadeiros para nós, ainda que não de modo absoluto. É precisamente nosso mundo, em cuja produção estamos constantemente engajados" (Nietzsche, 2006 [b], p. 130; KGW II 4.209-362). Busellato também menciona essa passagem em sua análise de Demócrito como uma influência do ceticismo nietzschiano de juventude ( $c f$. Busellato, 2012, p.140). Constâncio sugere ainda que Nietzsche, endossando, ao menos em parte, a visão kantiana de verdade partilhada por Lange, "denega que exista um conhecimento absoluto, mas admite que há verdades relativas" (Constâncio, 2017, p.106); "tal denegação da verdade absoluta não necessariamente implica uma negação da verdade relativa" (id. ibid., p.105). Em Sobre verdade e mentira no sentido extra-moral, Nietzsche descreve tais verdades como "inteiramente antropomórficas" e "privadas de qualquer 
propor que, para o jovem Nietzsche, o ceticismo é mais precisamente a consequência da negação kantiana do conhecimento absoluto (ou transcendente), quer dizer, da possibilidade mesma de se conhecer a verdade absoluta concernente à coisa em-si ou à essência das coisas. ${ }^{63}$ Tal como sublinhei, Nietzsche considera isso como algo derradeiramente indeterminado.

Agora me voltarei à segunda razão pela qual Nietzsche afirma que a filosofia kantiana poderia conduzir ao ceticismo e ao relativismo. Isso resvala no pressuposto axiológico que, tal como pretendo sugerir, encontra-se no centro do problema do ceticismo em SE/Co. Ext.III $\S 3$. Nos escritos de juventude, Nietzsche concorda aproximadamente com Kant com o fato de que a denegação do conhecimento absoluto significa que "nem a importância metafísica, nem a relevância ética ou estética da existência devem ser provadas" (Nachlass/ FP 1872, 19[123], KSA 1.459). Se nosso conhecimento relativo e limitado pode ou não contar como um tipo específico de verdade, eis algo que, para o jovem Nietzsche, não constitui uma fonte de valor suficiente para satisfazer as mais importantes necessidades morais e existenciais humanas. Hei de retornar a isso brevemente, mas por ora basta dizer que também aqui ele ainda está em relativa conformidade com Kant. No entanto - e esse é um ponto crucial -, Nietzsche permanece profundamente desconfiado em relação à doutrina kantiana da fé prática. E isso apesar de manifestar, nos póstumos de juventude, uma certa curiosidade acerca da tentativa de Kant de negar o conhecimento, para, aí então, criar espaço à fé, observando ainda que tal ação, afinal de contas, havia sido "guiada por uma necessidade cultural" - quer dizer, pela necessidade de resgatar o domínio prático do conhecimento ( $c f$. Nachlass/FP 1872,

elemento que pudesse ser 'verdadeiro em si', isto é, real e universalmente válido para além do ser humano" (WL/VM 1, KSA 1.883).

63 Cf. o seguinte fragmento: "o conhecimento absoluto celebra aqui (...) suas saturnálias" (Nachlass/ FP 1872, 19[37], KSA1.429).

Cad. Nietzsche, Guarulhos/Porto Seguro, v.40, n.3, p. 115-170, setembro/dezembro, 2019. 149 
Serini, L.

19[34], KSA 1.427; Cf. também Nachlass/FP 1872, 19[62], KSA 1.439). Num certo sentido, Nietzsche considera a tentativa kantiana de salvar o âmbito da ética da crítica ao conhecimento como algo semelhante a seu próprio projeto filosófico inicial. ${ }^{64}$ Apesar disso, é importante ter em mente que mesmo o Nietzsche de juventude rejeitaria o conteúdo de tal passo kantiano, isto é, sua tentativa de justificar praticamente nossas crenças nas coisas em si mesmas tais como Deus, imortalidade e liberdade - devido ao fato de elas serem ideias necessárias da razão. Tenciono enfatizar que, sob a ótica nietzschiana, ambas as leituras da filosofia kantiana empreendidas por Schopenhauer e Lange, respectivamente, contribuem para rejeitar a razão prática de Kant e, em especial, sua doutrina da fé prática. ${ }^{65}$ Para o jovem Nietzsche, as tentativas de determinar metafisicamente a coisa em-si enquanto "Deus", "Vontade" ou outras formas quaisquer "são criadas apenas com a ajuda de uma intuição poética."66 À diferença de Kant, portanto, Nietzsche considera as ideias de Deus e imortalidade como produtos livres e arbitrários da mente humana, e, além disso, como sendo praticamente "insuficientes (...) para responder às nossas mais profundas necessidades" (Nachlass/FP 1872, 19[34], KSA 1.427). ${ }^{67}$ Isso se torna igualmente patente nos escritos publicados e, em particular, em Schopenhauer como educador,

64. A respeito de uma discussão sobre a estratégia nietzschiana de juventude para criar espaço à arte e à ética, $c f$. Hill, 2003, pp. 113-114.

65 Em relação a Schopenhauer, $c f$. Schopenhauer, vol. I [“Apêndice”], 1969, pp. 522-523. Acerca disso, $c f$. também Lupo, 2019. Cf. ainda, por exemplo, o seguinte fragmento de Nietzsche: "[em Schopenhauer] a ideia de imortalidade desaparece, junto com o medo da morte", "a relação com Deus é abandonada", sendo que, em vez disso, encontramos a "ideia de que não nos é dado escapar à miséria da existência mediante medidas paliativas", tais como os remédios cristãos e a "piedade" (Nachlass/FP 1873, 28[6], KSA 1.618). No que tange a Lange, $c f$. sua História do materialismo (Lange, 2000, p. 155). Busellato (2012) menciona igualmente essa passagem ( $c f$. Busellato, 2012, pp.145-146). Cf., em especial, carta n 517 a Carl von Gersdorff, do fim de agosto 1866, KSB 2.159.

66 Cf. Nietzsche, 2009, [“Zu Schopenhauer”], p.3; Nachlass/FP 1867-1868, 57 [55], KGW I, 4.418-30.

$67 C f$., por exemplo, o seguinte fragmento: "Acreditar num Deus e num Redentor não passa de um acessório mitológico e nada tem a ver com a essência da religião" (Nachlass/FP 1874, 32[79], KSA 7.783). Cf. também Nachlass/FP 1872, 19[23], KSA 7.423 e Nachlass/FP 1873, 29[88], KSA 7.669-70. Em geral, Nietzsche considera a crença metafísica de que a verdade pode ser predicada

150 | Cad. Nietzsche, Guarulhos/Porto Seguro, v.40, n.3, p. 115-170, setembro/dezembro, 2019. 
onde Nietzsche acusa Kant de manter "a aparência da fé religiosa" (SE/Co. Ext. III 3, KSA 1.351) e de ter pouca coisa original para contribuir à reflexão moral.

Em SE/Co. Ext. III §3, como espero frisar, Nietzsche aponta para um problema fundamental de valor, que se acha à base de sua caracterização do efeito cético e relativista do kantismo como "corrosivo e desintegrador (SE/Co. Ext. III 3, KSA 1.355)." Pelas razões que acabei de indicar, ele interpreta a negação kantiana do conhecimento absoluto igualmente como uma denegação da possibilidade de se fiar, teórica e praticamente, nas coisas em si mesmas tais como Deus, imortalidade e liberdade: "Num certo sentido, a influência de Kant foi também nociva: pois a crença na metafísica foi perdia. Ninguém poderá contar com sua "coisa em-si"' (Nachlass/ FP 1872, 19[28], KSA 1.425). Assim, conforme a interpretação de Nietzsche, a filosofia teórica kantiana - a despeito do próprio passo prático dado por Kant - elimina a principal fonte valorativa da crença própria à moral e religião tradicionais que informam e guiam nossa inteira forma moderna de vida. ${ }^{68}$ Ademais, como já mencionei, nos escritos de juventude Nietzsche não acredita que aquilo que nos resta - isto é, aparências ou verdades relativas - pode constituir uma fonte adequada de valores éticos e existenciais. Ao longo das Considerações extemporâneas, ele se preocupa continuamente com o problema das carências humanas, quer dizer, com o que se mostra necessário aos seres humanos para viver uma vida saudável e florescente. ${ }^{69}$

da natureza das coisas como sendo uma projeção psicológica. Cf. Nachlass/FP 1872, 19[175], KSA 7.473 e Nachlass/FP 1872, 19[229], KSA 7.491.

68 Nesse sentido, Nietzsche observa que "estamos vivendo às custas do capital moral herdado e acumulado por nossos ancestrais, um capital que já não sabemos mais como ampliar, mas apenas como dilapidar" (SE/Co. Ext. III 2, KSA 1.344). Comparar com Nietzsche, 2006 (a), pp.12-15; Nachlass/FP 1862, 13 [6], KGW I, 2.430-37

69 Que se considere, por exemplo, o principal argumento desenvolvido em HL/Co. Ext. II. Em tal Consideração extemporânea, Nietzsche examina criticamente até que ponto a história - tanto no sentido do passado quanto em termos de representações do passado, da memória à historiografia científica - é exigida para a saúde e florescimento dos indivíduos, de um povo e uma cultura $(c f$.

Cad. Nietzsche, Guarulhos/Porto Seguro, v.40, n.3, p. 115-170, setembro/dezembro, 2019. | 151 
Ainda sob uma forte influência da concepção schopenhaueriana da necessidade metafísica dos seres humanos, ${ }^{70}$ no período de juventude Nietzsche sustenta que, embora não nos seja dado conhecer coisa alguma acerca de uma verdade absoluta, a crença de que nossas esperanças morais e existenciais, bem como nossas formas de vida, estão alicerçadas sobre algo firme, seguro e não relativo possui, no final das contas, um enorme valor e talvez até seja imprescindível para a vida humana: "Possuir, em crença, a verdade, eis o que torna possível a mais elevada e pura vida. $\mathrm{O}$ ser humano carece da crença na verdade" (Nachlass/FP 1872, 19[175], KSA 7.473). ${ }^{71}$

Nesse sentido, portanto, no entender de Nietzsche, o kantismo oferece um perigo a certos pensadores (como Kleist) e pode inclusive exercer um efeito destrutivo sobre a cultura de sua época: ele demonstra que não temos conhecimento e, quiçá, não podemos ter conhecimento de uma fonte valorativa absoluta para nossas necessidades éticas e existenciais mais profundas (isto é, as necessidades de fazer

HL/Co. Ext. II 1, KSA 1.248). Por diversas vezes, Nietzsche sugere que uma das tarefas do filósofo enquanto médico da cultura é a de distinguir as "verdadeiras necessidades" ( $c f$. HL/Co. Ext. II 5, KSA 1.279) ou "genuínas carências" ( $c f$. HL/Co. Ext. II 10, KSA 1.324) das "necessidades ilusórias" (cf.WB/Co. Ext. IV 8, KSA 1.472) ou "pseudo-necessidades" (cf. HL/Co. Ext. II 10, KSA 1.324). Cumpre notar que Nietzsche analisa essas necessidades primordialmente do ponto de vista da antropologia, psicologia e crítica cultural.

70 Cf. Schopenhauer, v. II, 1969, §17. Tal como observou Keith Ansell-Pearson, nos escritos relativos ao período intermediário, "Nietzsche sustenta que a necessidade metafísica não é a fonte da religião, tal como se poderia supor, senão que o afeto que se segue ao seu declínio: a 'necessidade' é um resultado e não uma origem" (Ansell-Pearson, 2018, p.155 [nota 32]). Para acompanhar o desenvolvimento da concepção nietzschiana inicial da necessidade metafísica, $c f$. Nachlass/FP 1872, 19[85], KSA 7.448; Nachlass/FP 1876, 23[21], KSA 8.411; Nachlass/FP 1876, 23[64], KSA 8.425; Nachlass/ FP 1876, 28[6], KSA 8.504; WS/AS 16, KSA 2.550; Nachlass/FP 1880, 6[290], KSA 9.271; FW/ GC 151, KSA 3.494.

71 Cf. também Nachlass/FP 1872, 19[245], KSA 7.496; Nachlass/FP 1872, 19[253], KSA 7.498; Nachlass/FP 1872, 19[254], KSA 7.499; Nachlass/FP 1873, 21[13], KSA 7.526; Nachlass/FP 1873, 29[8], KSA 7.623; e Nachlass/FP 1873, 29[17], KSA 7.632. Nesse sentido, Nietzsche observa que a "suprema prosperidade dos seres humanos reside, antes do mais, em ilusões" (Nachlass/FP 1873, 29[8], KSA 7.623), em algo que não podemos conhecer em termos absolutos, mas em que nos é necessário acreditar a fim de viver uma vida bem-aventurada e florescente. 
frente à morte e ao sofrimento). ${ }^{72}$ Essa discrepância e tensão entre o conhecimento (ou, mais especificamente, aquilo que não nos é facultado conhecer) e nossas necessidades constitui, na terminologia nietzschiana, o caráter trágico da existência humana. A denegação kantiana de um conhecimento absoluto revela, em especial, "a natureza trágica e, de fato, resignada do conhecimento" ( $c f$. Nachlass/ FP 1872, 19 [248], KSA 7.497; Cf. também Nachlass/FP 1872, 19[319], KSA 7.517), comprovando que há coisas que gostaríamos de conhecer, mas, infelizmente, não podemos fazê-lo (GT/NT 18, KSA 1.115). Confrontado com o perigo de uma tal "resignação trágica", Nietzsche afirma que "apenas a arte é capaz de nos salvar" (Nachlass/FP 1872, 19 [319], KSA 7.517). Não é de admirar, pois, que enfatize a "necessidade da arte e da ilusão" para combater um "ceticismo absoluto" (Nachlass/FP 1872, 19[21], KSA 7.422; Cf. também Nachlass/FP 1872, 19[52], KSA. 7.436). A resposta de Nietzsche ao problema do ceticismo será o tópico da próxima parte deste artigo. Em conclusão a esta seção, gostaria apenas de sublinhar que a dimensão axiológica do ceticismo presente em SE/Co. Ext. III $\$ 3$ antecipa, sob várias formas, o tardio interesse nietzschiano pelo niilismo. De fato, tal como Sommer acertadamente observou, "em sua obra inicial, quando a fórmula para o niilismo ainda não estava à disposição de Nietzsche, fenômenos ocasionais que mais tarde serão classificados como niilistas (e.g. HL/Co. Ext. II §8), são subsumidos sob a rubrica do "ceticismo." 73 A esse respeito, Lupo salientou igualmente que, para Nietzsche, em SE/Co. Ext. III §3, o desespero da verdade causado pelas consequências relativistas -

72 Lupo apontou acertadamente que o problema do relativismo - assim como o do ceticismo - não se restringe, em SE/Co. Ext. III §3, à epistemologia, senão que diz respeito, em especial, às consequências éticas e existenciais de uma teoria do conhecimento que denega o acesso à esfera da verdade e transcendência absolutas, reduzindo a realidade a um conjunto de relações ( $c f$. Lupo, 2019, p.128).

$73 C f$. Sommer, 2006, p. 265. Sobre o vínculo nietzschiano tardio entre ceticismo e niilismo, $c f$. Sommer, 2006 e Busellato, 2012, pp. 293-301.

Cad. Nietzsche, Guarulhos/Porto Seguro, v.40, n.3, p. 115-170, setembro/dezembro, 2019. | 153 
Serini, L.

gostaria de realçar mais coisas a propósito ${ }^{74}$ - e céticas da filosofia kantiana é "uma condição não apenas epistemológica, senão que também, ao mesmo tempo, afetiva e emocional, e parece constituir uma espécie de prenúncio e matriz do niilismo."75

\section{O papel do filósofo em relação ao ceticismo.}

Na parte anterior, identifiquei os pressupostos teóricos derivados da filosofia kantiana que subjazem ao problema do ceticismo em SE/ Co. Ext. III §3. São eles: (a) o pressuposto epistêmico de que não nos é dado obter um conhecimento absoluto (amparado pelo pressuposto epistêmico de que podemos ter apenas um conhecimento relativo); (b) o pressuposto metafísico de que a coisa em-si é indeterminada; (c) o pressuposto axiológico (em contraposição a Kant) de que (a) e (b) eliminam a coisa em-si como uma fonte de valor em termos morais e existenciais. Tal como argumentei até aqui, ao longo do presente artigo, Nietzsche toma esses pressupostos por verdadeiros, porém mortais. Vimos que ele considera o ceticismo como algo letal, na medida em que este expõe pensadores específicos (como Kleist) ao perigo do desespero pela verdade e poderia representar, potencialmente, uma ameaça à inteira cultura de sua época, indicando que as crenças morais e religiosas que dão forma e direção ao moderno modo de vida são, em realidade, privadas de fundamento racional. ${ }^{76}$

74 De fato, ao desenvolver seu argumento em SE/Co. Ext. III §3, Nietzsche deixa de lado sua referência ao relativismo e continua discutindo tão somente o ceticismo, relacionando este último ao papel do filósofo exemplificado por Schopenhauer.

$75 C f$. Lupo, 2019, p. 128. Acerca do vínculo entre desespero e uma forma particular de niilismo na filosofia de Nietzsche, $c f$. Reginster, 2006, p. 28.

76 Nietzsche não é o único filósofo a interpretar o ceticismo como um efeito destrutivo da filosofia kantiana sobre a vida humana. Como observou Paul W. Franks, "não é incomum, para um filósofo que se considera um kantiano, pensar que, longe de superar o ceticismo, Kant teria mostrado quão profundamente problemático ele de fato é, ou, então, que o próprio Kant teria trazido à tona um ceticismo ainda mais radical do que qualquer outro até então conhecido" (Franks, 2005, p. 154). Além disso, Franks sublinha que "alguns críticos de Kant talvez critiquem o idealismo transcendental, porque acreditam que este último equivale a alguma espécie nova de ceticismo habilitado pela revolução

154 | Cad. Nietzsche, Guarulhos/Porto Seguro, v.40, n.3, p. 115-170, setembro/dezembro, 2019. 
Em função disso, Nietzsche afirma que "ninguém pode viver com esse ceticismo derivado da filosofia kantiana", ${ }^{77}$ e que "temos ir além de tal ceticismo, sendo-nos necessário esquecê-lo!" (Nachlass/FP 1872, 19[125], KSA). Como podemos ir além e esquecer do ceticismo? Como vimos, em Schopenhauer como educador, Nietzsche assevera que Schopenhauer - ou, mais precisamente, seu exemplo educativo - ensina-nos como superar o ceticismo e como não terminar por cair em desespero, tal como Kleist (cf. SE/Co. Ext. III 3, KSA 1. 188). $\mathrm{Na}$ quarta e última parte deste artigo, tratarei de enfatizar o papel que Nietzsche atribui ao verdadeiro filósofo, exemplificado por Schopenhauer, em relação ao ceticismo e, em especial, ao problema axiológico que particularizei logo acima. Isso, creio, deverá tornar-se mais inteligível à luz de nossa consideração acerca das principais

\footnotetext{
kantiana, ao passo que alguns pós-kantianos talvez acreditem que sua adoção da revolução kantiana torne $o$ advento de algumas novas formas de ceticismo uma fonte de ansiedade para eles" (Franks, 2005, p. 147 [nota 1]). Esse é justamente o caso da primeira recepção da Crítica da razão pura. Sobre a história da primeira recepção de Kant na filosofia alemã, $c f$. Beiser, 1987. Como o próprio jovem Nietzsche, por exemplo, Carl Friedrich Stäudlin, autor de História e espírito do ceticismo (1794), tinha receio de que a filosofia kantiana pudesse conduzir a um ceticismo destrutivo, capaz de causar algum perigo à cultura de sua época: "O ceticismo começa a se tornar uma doença em nossa época e a se espalhar - algo que raramente aparece na história - em meio a um número maior de classes, expressando sua influência em grande escala (...) A última revolução em filosofia", o kantismo, a seu ver, "foi causado por ele, tornando-o, novamente, num objeto de uma profunda investigação filosófica" (Laursen, 2015, p. 274). Sobre o interesse de Stäudlin acerca de Kant, $c f$. igualmente Laursen, 2015. Jacobi é um outro pensador que vincula a filosofia kantiana a uma forma destrutiva de ceticismo, ligando-o inclusive ao problema do niilismo. Tal como relatou Beiser, "Jacobi possui um termo marcante para designar as consequências céticas de toda investigação filosófica [e, em particular, do criticismo kantiano]: 'niilismo' (Nihilismus). De fato, ele é responsável por introduzir essa palavra em seu uso geral na filosofia moderna (...) O niilista é alguém que nega a existência de tudo aquilo que independe dos conteúdos imediatos de sua própria consciência, sejam eles objetos externos, outras mentes ou Deus (...) O niilista denega a existência não apenas de coisas, senão que de valores também. E, já que nega a existência de um mundo exterior, de outras mentes, uma alma e Deus, o niilista desonera-se a si mesmo de toda obrigação em relação a tais pseudo-entidades" (Beiser, 1987, pp. 81-82). Cf. também Beiser, 1987, pp. 3-5. Embora Jacobi não fosse uma das fontes diretas de Nietzsche, creio que ambos identificam um problema filosófico análogo: para eles, a negação kantiana da possibilidade de se conhecer as coisas em si mesmas equivale, em grande medida, à negação da existência de objetos transcendentes moral e existencialmente relevantes, tais como Deus, imortalidade e liberdade. Isso corresponderia, por seu turno, à negação do valor de tais objetos supra-sensíveis para a vida humana.
}

77 Cf. também Nachlass/FP 1873, 29[8], KSA 7.623 e Nachlass/FP 1874, 30[14], KSA. 7.736.

Cad. Nietzsche, Guarulhos/Porto Seguro, v.40, n.3, p. 115-170, setembro/dezembro, 2019. | 155 
preocupações de Nietzsche em Schopenhauer como educador (primeira parte), particularmente no que tange àquilo que ele entende ser as mais importantes tarefas da filosofia (segunda parte).

Tenciono defender que, na terceira Consideração extemporânea, assim como em outros escritos de juventude, Nietzsche sustenta que o filósofo não deveria intervir no "verdadeiro" lado do ceticismo, senão que na sua faceta "letal". O que conto dizer com isso? Que, para Nietzsche, a resposta filosófica apropriada ao ceticismo não deveria ser dada no território da epistemologia e da metafísica. Afinal de contas, ele acredita que os pressupostos kantianos que causam o ceticismo são verdadeiros - isto é, que não podemos conhecer verdades absolutas. Espero sugerir, em vez disso, que a tarefa do filósofo é a de neutralizar, de algum modo, a letalidade e periculosidade do ceticismo em relação à vida humana. ${ }^{78}$ Essa tarefa, tal como afirma Nietzsche, deveria ser levada a cabo no âmbito da filosofia entendida como arte e sabedoria. ${ }^{79}$ Sob minha perspectiva, essa resposta um tanto quanto idiossincrática ao ceticismo diz respeito, sobretudo, ao problema de como viver e florescer a despeito do ceticismo.

Gostaria de iniciar lançando diretamente um olhar sobre SE/ Co. Ext. III §3. Uma vez mais, Nietzsche opõe Schopenhauer aos eruditos:

Sua grandeza reside no fato de ter lidado com a imagem da vida [Bilde des Lebens] como um todo, no intuito de interpretá-la como um todo ${ }^{80}$ enquanto os intelectos mais sagazes não podem livrar-se da noção equivocada de que se chega mais perto dessa interpretação à medida em que se investiga

78 De fato, nos escritos de juventude, para Nietzsche, "o valor da filosofia não reside na esfera do conhecimento, mas na esfera da vida" (Nachlass/FP 1872, 19[45], KSA 7.433).

79 Busellato também explora esse ponto, enfatizando a importância da concepção nietzschiana de filosofia como arte ( $c f$. Busellato, 2012, pp. 155-190). Nesta parte do artigo, em vez disso, trato de dar maior ênfase à relevância da concepção nietzschiana de filosofia como sabedoria, e não como disciplina acadêmica e científica. É claro, porém, que essas duas concepções estão inter-relacionadas.

80 Sobre a noção schopenhaueriana de imagem da vida, $c f$. Schopenhauer, v. II, 1969, p. 379; Schopenhauer, vol. II, 1974 (a), pp. 4-5 e p. 646.

156 | Cad. Nietzsche, Guarulhos/Porto Seguro, v.40, n.3, p. 115-170, setembro/dezembro, 2019. 
meticulosamente as cores com as quais e o material sobre o qual a imagem foi pintada - e isso apenas para chegar, então, à conclusão de que se trata de uma tela intricadamente urdida e com cores cuja composição química é inexplicável [...] Agora, porém, a inteira comunidade acadêmica, em todas as áreas do conhecimento, está ocupada em entender tal tela e tais cores, mas não a própria imagem. ${ }^{81}[\ldots]$ Pois sem a pedra de toque fornecida por uma tal imagem de conjunto, tais campos do conhecimento permanecem malhas desprovidas de qualquer fim, servindo meramente para tornar o nosso caminho pela vida mais confuso e labiríntico [...] A grandeza de Schopenhauer está em perseguir tal imagem [...] sem se deixar distrair, tal como ocorre com os eruditos, ou, então, sem ser emaranhado por uma teia de conceitualizações escolásticas [...] Eis o que exige toda grande filosofia, que, como uma totalidade, sempre diz tão somente: "Essa é a imagem da vida." E, por outro lado: "lê tua vida e decifra, com base nela, os hieróglifos da vida em geral" (SE/Co. Ext. III 3, KSA 1.356-57).

Nessa passagem, Nietzsche identifica o grande mérito da resposta de Schopenhauer ao ceticismo em sua tentativa de lidar com "a imagem total da vida" em contraposição à estreiteza de visão erudita. ${ }^{22}$ Tal como Nietzsche a descreve, trata-se, antes de mais nada, de uma tentativa de olhar para existência como um todo, implicando ir além da especialização e fragmentação do discurso filosófico acadêmico. Enquanto dos debates eruditos é "permitido cismar, duvidar e contradizer" (SE/Co. Ext. III 3, KSA 1.357), Schopenhauer, ao perseguir uma imagem compreensível da vida,

81 Que se compare com a seguinte passagem: "Em geral, seu campo de visão [do erudito] é bastante pequeno, sendo-lhe necessário pressionar seus olhos bem rente ao objeto por ele visado. Se conta proceder de um ponto da investigação a outro, ele é obrigado a deslocar seu inteiro aparato visual na direção de tal ponto. Ele disseca uma imagem em nada mais exceto manchas coloridas, como alguém que, na ópera, utiliza um monóculo para melhor enxergar o palco, mas com isso termina por entrever somente uma cabeça e, depois, um pouco de vestimenta etc., porém jamais conseguindo focalizar em nada tomado como um todo (...) [ele] estaria tentado a sustentar que uma pintura a óleo não passa de uma massa de manchas" (SE/Co. Ext. III 6, KSA 1.395).

82 Nos escritos do período intermediário, Nietzsche irá mudar completamente sua visão a esse respeito: "A tarefa de pintar $o$ quadro da vida, por mais frequentemente que tenha sido colocada por poetas e filósofos, é não obstante um disparate: mesmo nas mãos dos maiores pintores-pensadores foram produzidas sempre apenas imagens e miniaturas de uma vida singular, quer dizer, de suas próprias vidas - e nada além disso seria sequer possível" (VM/OS 19, KSA 2.387).

Cad. Nietzsche, Guarulhos/Porto Seguro, v.40, n.3, p. 115-170, setembro/dezembro, 2019. | 157 
Serini, L.

visa a fornecer uma pedra de toque capaz de nos mostrar, à guisa de orientação, como viver. Pretendo enfatizar precisamente esse aspecto da descrição nietzschiana acerca da edificante resposta ao ceticismo dada por Schopenhauer. Nietzsche já havia tocado nesse ponto em O nascimento da tragédia (1872), elogiando Schopenhauer por ter fornecido uma visão trágica:

Essa visão marca o início de uma cultura que agora ouso descrever como cultura trágica. Seu traço característico mais importante está em colocar, como objetivo mais elevado, a sabedoria no lugar da ciência. Essa sabedoria não se deixa enganar pelas distrações sedutoras das ciências, mas, ao contrário, volta seu olhar inabalável em direção à imagem global do mundo, visando a abarcar, nessa imagem, o sofrimento eterno com sentimentos empáticos de amor, reconhecendo-o, assim, como seu próprio sentimento (GT/NT 18, KSA 1.118).

A essa altura, deveria estar claro que a imagem global da vida, sobretudo na terceira Consideração extemporânea, não consiste na caracterização metafísica schopenhaueriana da coisa em-si como Vontade. De fato, Nietzsche fala de um quadro ou de uma imagem [Bild] da vida, em vez de uma explicação metafísica a propósito na natureza íntima do mundo.

Vale notar que o próprio Schopenhauer identificava seu mérito filosófico tanto em relação ao efeito destrutivo da filosofia de Kant quanto no que se refere ao desespero kantiano. No "Apêndice" ao Primeiro Volume d'O mundo como vontade e representação, Schopenhauer escreve que a filosofia crítica de Kant desmontou

em pedaços a inteira maquinaria de nossas faculdades de conhecimento, de sorte que, com isso, a fantasmagoria do mundo objetivo é trazida à baila, apresentando-o pouco a pouco, fragmentadamente, com maravilhosa habilidade e visão das coisas. Toda filosofia ocidental anterior, que então parece indizivelmente desajeitada, quando comparada com a filosofia kantiana, foi incapaz de reconhecer aquela verdade e, em realidade, portanto, sempre tomou a palavra como se estivesse num sonho. Kant foi

158 | Cad. Nietzsche, Guarulhos/Porto Seguro, v.40, n.3, p. 115-170, setembro/dezembro, 2019. 
o primeiro a ter despertado, de repente, desse sonho; por isso, os últimos dorminhocos (Mendelssohn) denominaram-no aquele a que tudo tritura. ${ }^{83}$

Schopenhauer refere-se a Moses Mendelsohn, um filósofo contemporâneo de Kant e considerado, habitualmente, o último metafísico tradicional à maneira de Leibniz e Wolff. No prefácio às Horas matinais (1785), Mendelsohn chamou Kant, como bem se sabe, de o 'tritura-tudo' [Alleszermalmende], quer dizer, aquele que destruiu a metafísica tradicional e, com isso, colocou em perigo todas as crenças morais e religiosas amparadas pelo conhecimento transcendente..$^{84}$ A reação de Mendelssohn relativamente a Kant é, nesse sentido, análoga à reação de Kleist. Ora, para Schopenhauer, Kant demonstrou a "impossibilidade de nossa capacidade para provar todos aqueles dogmas que eram supostamente tidos como comprovados [pela metafísica tradicional]. A teologia especulativa e a psicologia racional a ela vinculada receberam, dele, seu golpe fatal." ${ }^{95}$ Schopenhauer reconhece o efeito destrutivo do kantismo não somente na esfera metafísica, senão que também na religião e na moral. ${ }^{86}$ No capítulo "Sobre a necessidade metafísica humana", Schopenhauer defende notoriamente que, enquanto as crenças religiosas podem

83 Schopenhauer, v. I, 1969, p.420.

84 Tal explicou Frederick C. Beiser mais detalhadamente, para Mendelssohn, "Kant é o cético ou niilista, já que destrói a metafísica necessária para justificar a crença moral e religiosa (...) O idealismo de Kant é o maior perigo à sua filosofia, segundo Mendelssohn. É uma afronta ao senso comum e uma ameaça à moralidade e à religião. Como podemos agir no mundo, como podemos levar a cabo nossas obrigações e como podemos adorar a um Deus, se pensarmos que tudo é feito simplesmente de representações? A interpretação de Mendelssohn do idealismo kantiano é típica da Popularphilosophie [filosofia popular] de sua época. Assim como Garve, Feder e Weishaupt, Mendelssohn não vê uma diferença essencial entre o idealismo de Kant e Berkley. Seja como kantiano, seja como berkeliano, o idealista sustentaria que nada existe senão que substancias espirituais; e ele denega a existência de um objeto exterior correspondente às suas representações. Mendelssohn também pressupõe, equivocadamente - e, mais uma vez, em coro com Garve, Feder e Weishaupt -, que Kant não afirma, mas apenas nega a existência das coisas em si mesmas" (Beiser, 1987, pp. 105-106).

85 Schopenhauer, v. I [“Apêndice”], 1969, p. 423.

86 No que concerne à moralidade, Schopenhauer acrescenta ainda que, sem a metafísica, a física ou o naturalismo "seriam destrutivos à ética" ( $c f$. Schopenhauer, v. II, 1969, p. 175).

Cad. Nietzsche, Guarulhos/Porto Seguro, v.40, n.3, p. 115-170, setembro/dezembro, 2019. 159 
afirmar a verdade apenas num sentido alegórico, "a tentativa de fundar a religião na razão [...] coloca-a sob o tiroteio do ceticismo e sob a pesada artilharia da Crítica da razão pura." 87 No "Apêndice", Schopenhauer também associa esse efeito destrutivo ao desespero: considera seu projeto filosófico como um "caminho intermediário entre a doutrina da onisciência do dogmatismo precedente e o desespero da Crítica kantiana". ${ }^{88}$

É provável que, em SE/Co. Ext. III §3, Nietzsche tenha em mente essas passagens ao apresentar Schopenhauer como um condutor apto a guiar para fora da caverna do ceticismo. Como vimos, no entanto, ao menos desde 1868, Nietzsche não acreditava na metafísica de Schopenhauer e tampouco na base metafísica de sua ética. Se, por um lado, portanto, Nietzsche reconhece o mérito de Schopenhauer de ter detectado o problema da existência e de como viver, por outro, ele rejeita a tentativa desse último de superar o desespero da filosofia kantiana mediante sua metafísica da Vontade, bem como seu intento simultâneo para fornecer um fundamento metafísico à moralidade. Além disso, tal como expliquei na seção anterior, Nietzsche recusa a estratégia de Kant de responder ao ceticismo teórico por meio de sua doutrina da fé prático-racional, a qual ainda é, de qualquer modo, metafísica. Cumpre frisar que o jovem Nietzsche também rechaçaria um culto meramente irracional da vida (tal como, por exemplo, o de Jacobi), ${ }^{89}$ assim como recusaria uma mera adesão à

87 Schopenhauer, v. II, 1969, p.168 e p.181. Nietzsche está bem ciente disso: "Para criar uma religião, ter-se-ia de despertar a crença numa num edifício mítico construído num vácuo [...] Desde a Crítica da razão pura, é muito improvável que isso volte a acontecer algum dia" (Nachlass/FP 1872, 19 [39], KSA 7.431).

88 Schopenhauer, v. I [“Apêndice”], 1969, p.428; $c f$. também Schopenhauer, v. II, 1969, p. 172. É interessante notar que, na Crítica da razão pura, o próprio Kant considerou seu projeto crítico em oposição tanto aos dogmáticos quanto aos céticos ( $c f$. Kant, 1989, Aix-Ax), ao idealismo e ao ceticismo ( $c f$. Kant, 1989, Bxxxiv), e mesmo em contraposição à desesperança cética ( $c f$. Kant, 1989, B434).

89 Como bem se sabe, a estratégia de Jacobi para evitar as consequências niilistas do ceticismo consiste em promover uma forma de fideísmo irracional, isto é, um salto mortale místico ou salto da fé que requer uma certa força intelectual no intuito de domar as exigências críticas da razão.

160 | Cad. Nietzsche, Guarulhos/Porto Seguro, v.40, n.3, p. 115-170, setembro/dezembro, 2019. 
moral tradicional e às crenças religiosas. Por um lado, sob a ótica nietzschiana, o filósofo genuíno exemplificado por Schopenhauer está fortemente comprometido com uma forma de veracidade capaz de destruir tudo aquilo que pode ser negado, visando a uma existência "que é verdadeira em si mesma e livre de falsidade $;{ }^{90}$ por outro lado, tal como enfatizei na primeira parte, a filosofia deveria almejar modos autênticos de existência em oposição aos costumes e opiniões de sua própria época (Cf. SE/Co. Ext. III 1, KSA 1.337).

Qual é, então, segundo Nietzsche, a resposta adequada ao ceticismo? Nos póstumos, ele oferece uma resposta mais clara a essa questão: "Nossa salvação [do ceticismo] não está no conhecer, mas no criar (Nachlass/FP 1872, 19[125], KSA 7.459). ${ }^{91}$ Ou:

O filósofo do conhecimento trágico. Ele controla o desenfreado impulso ao conhecimento, mas não mediante uma nova metafísica. Não estabelece uma nova fé. Ele sente como algo trágico que o chão da metafísica tenha sido removido e nunca pode satifazer-se com o colorido caleidoscópio das ciências. Trabalha para construir uma nova vida; devolve à arte os seus direitos. O filósofo do conhecimento desesperado será consumido pela ciência cega: conhecimento a todo custo. Para o filósofo trágico, a imagem da existência é formada completamente pela ideia de que o metafísico aparece apenas sob forma antropomórfica. Ele não é um cético. Aqui, é preciso criar um conceito, pois o ceticismo não é o objetivo. $\mathrm{O}$ impulso ao conhecimento, uma vez atingido seus limites, dirige-se contra si mesmo,

90 Cf. SE/Co. Ext. III 4, KSA 1.271; cf. também HL/Co. Ext. II 10, KSA 1.324. Que se compare ainda com esse relevante fragmento: "Sonho com uma comunidade de homens que sejam incondicionados, que desconhecem proteção e querem ser chamados de 'destruidores'; aplicam a medida de sua crítica a tudo e sacrificam-se a si mesmos à verdade. O ruim e ofalso devem ser trazidos à luz! Não queremos construir nada prematuramente, tampouco sabemos se jamais poderemos construir ou se não seria melhor não construir. Há pessimistas preguiçosos, pessoas resignadas - não queremos fazer parte delas" (Nachlass/FP 1875, 5 [30], KSA 8.48).

91 Nietzsche, por exemplo, faz a seguinte proposta: "O que deveria fazer o filósofo? Em meio ao enxame formigante, ele deve enfatizar o problema da existência, os eternos problemas em geral. $\mathrm{O}$ filósofo deve reconhecer aquilo que se faz necessário e o artista deve criá-lo" (Nachlass/FP 1872, 19[23], KSA 7.423); "Se pudéssemos criar os costumes, costumes poderosos! Então, com isso, também teríamos a moralidade. Mas os costumes são formados a partir dos exemplos estabelecidos por personalidades poderosas" (Nachlass/FP 1872, 19[39], KSA 7.431).

Cad. Nietzsche, Guarulhos/Porto Seguro, v.40, n.3, p. 115-170, setembro/dezembro, 2019. | 161 
para então passar à crítica do conhecimento. $\mathrm{O}$ conhecer a serviço da vida melhor. Deve-se desejar a própria ilusão - nisso consiste o trágico (Nachlass/ FP 1872, 19[35], KSA 7.428).

Nesse fragmento, Nietzsche define significativamente o papel do filósofo e a tarefa da filosofia em oposição ao ceticismo: o filósofo não é um cético e o ceticismo não é o objetivo da filosofia. O filósofo deveria responder ao ceticismo mediante a criação de um conceito e ao colocar o conhecimento a serviço da vida. ${ }^{92}$ Mas o que significa criar um conceito? Como isso se coaduna com o exemplo educativo de Schopenhauer presente em SE/Co. Ext. III §3? E qual é a pedra de toque fornecida pela busca schopenhaueriana por uma imagem total da vida?

Como bem se sabe, na literatura secundária, numa importante carta de 1866, Nietzsche comenta entusiasmadamente a proposta de Lange segundo a qual, após a morte da metafísica tradicional - e, em certa medida, igualmente da metafísica schopenhaueriana -, a filosofia deveria ser compreendida como uma arte voltada à edificação e elevação dos seres humanos mediante a construção de ideais estéticos e morais, os quais, ainda que não fundados no conhecimento teórico, seriam necessários para propiciar significado à vida. ${ }^{93}$ À luz disso, na carta, Nietzsche sugere que Schopenhauer, mesmo privado

92 Não considerarei, aqui, o papel do filósofo em relação àquilo que Nietzsche chama de desejo de ilusão.

93 Cf. carta ${ }^{\circ} 517$ a Carl von Gersdorff, do fim de agosto 1866, KSB 2.159; $c f$. também, por exemplo, Nachlass/FP 1872, 19[36], KSA 7.428 e Nachlass/FP 1872, 19[39], KSA 7.431. Sobre a interpretação nietzschiana do ponto de vista de Lange acerca do ideal, $c f$. Stack, 1983, pp. 11-12 e 302-332. A respeito de uma discussão sobre se o Nietzsche da maturidade permanece (ou não) comprometido com a afirmação de Lange segundo a qual realidade precisa ser complementada com um ponto de vista ideal, $c f$. Ansell-Pearson, 1988 e Constâncio, 2017. Keith Ansell-Pearson defendeu, em chave crítica, que o ponto de vista de Lange acerca do ideal, reproduzindo o caráter fundamentalmente dualista do pensamento kantiano, é incompatível com a filosofia nietzschiana da maturidade, e, em especial, com sua crítica ao ideal ascético. Ao passo que João Constâncio, por sua vez, alegou que "Nietzsche jamais abandonou realmente a ideia de que a filosofia é, em parte, algo semelhante à 'arte' e, sobretudo, que filosofia tem algo a ver com 'edificação'. No período de maturidade, isso se converte na ideia de que a filosofia tem a ver com 'criar valores', ou, então, que a tarefa dos filósofos é levar a cabo uma 'transvaloração dos valores' afirmadora de vida” (Constâncio, 2017, p.107).

162 | Cad. Nietzsche, Guarulhos/Porto Seguro, v.40, n.3, p. 115-170, setembro/dezembro, 2019. 
de sua metafísica da Vontade, ${ }^{94}$ ainda nos permaneceria crucialmente importante enquanto arte e ideal edificante.$^{95} \mathrm{O}$ que há, pois, apesar de tudo, de edificante em Schopenhauer? No texto, embora Nietzsche faça alusão a algumas doutrinas centrais da ética schopenhaueriana como antídotos e formas de consolo, ${ }^{96}$ espero defender que o exemplo educativo de Schopenhauer em relação ao ceticismo não reside necessariamente no conteúdo de sua ética, senão que, ante do mais, em sua ênfase nas necessidades morais e existenciais mais profundas, bem como na tentativa de elaborar uma sabedoria filosófica apta a oferecer uma orientação sobre como viver. Ao contrário do que ocorre com Kant e os filósofos acadêmicos, Nietzsche salienta que o que há de "curioso no surgimento de Schopenhauer [...] é o fato de ele chegar aos problemas primordiais mais profundos da ética e da arte, levantando, assim, a questão pelo valor da existência" (Nachlass/FP 1872, 19[28], KSA7.425). Ainda que em oposição à ética metafisicamente fundada de Schopenhauer, Nietzsche percebe que, "por ora, não vejo outra possibilidade à práxis senão que a sabedoria schopenhaueriana do mundo, uma sabedoria voltada às necessidades mais profundas" (Nachlass/FP 1873, 30[15], KSA $7.738) \cdot{ }^{97}$

Dito isso, gostaria de observar, à guisa de conclusão, que o ceticismo não possui apenas uma relevância exclusivamente negativa na filosofia nietzschiana de juventude. De fato, GT/NT §18 e SE/Co.

940 próprio Schopenhauer pensava que filosofia e arte procuram, de fato, responder a mesma questão, ainda que de modos distintos: "não apenas a filosofia, mas também as belas-artes trabalham, no fundo, para encontrar a solução ao problema da existência” (Schopenhauer 1969, v. II, p. 406). Cf. também Schopenhauer, v. I, §49.

$95 C f$. carta ${ }^{\circ} 517$ a Carl von Gersdorff, do fim de agosto 1866; KSB 2.159. Sobre a reconstrução "estética" de Schopenhauer, $c f$. Gardner, 2015, pp. 133-134.

96 "Quais sejam: sacrifício do ego e sujeição às mais nobres intenções, sobretudo à justiça e compaixão. Ele [Schopenhauer] nos ensina a distinguir entre os verdadeiros e os meramente aparentes promotores da felicidade; como nem riqueza, nem honra ou educação podem retirar o indivíduo de sua profunda depressão pela inutilidade de sua existência" (SE/Co. Ext. III 3, KSA 1.357).

97 Aqui, Nietzsche deve referir-se muito provavelmente aos "Aforismos para a sabedoria de vida", em Parerga e Paralipomena, e não a $O$ mundo como vontade e representação.

Cad. Nietzsche, Guarulhos/Porto Seguro, v.40, n.3, p. 115-170, setembro/dezembro, 2019. | 163 
Serini, L.

Ext. III $§ 3$ dão a entender que o ceticismo causado pela limitação kantiana do conhecimento aos fenômenos também constitui, num certo sentido, algo positivamente relevante (Cf. também Nachlass/FP 1872, 19[322], KSA 7.518). A ameaça cética nos permite identificar uma tarefa essencial, embora negligenciada, da filosofia: a de buscar uma sabedoria (conhecimento a serviço da vida) capaz de acertar as contas com os problemas axiológicos que confrontam o sistema de crenças que dá forma e direção ao nosso moderno modo de vida.

\section{Conclusão}

Espero ter esclarecido, no presente artigo, a concepção nietzschiana de ceticismo contida em SE/Co. Ext. III §3, considerando-a no contexto de suas principais preocupações em Schopenhauer como educador e nos quadros pós-kantianos de sua filosofia de juventude. Sugeri, em especial, que o ceticismo constitui, para o jovem Nietzsche, uma doutrina verdadeira, porém mortal. Tentei mostrar aquilo que Nietzsche toma por verdadeiro nele, salientando os pressupostos epistemológicos, metafísicos e axiológicos que derivam da filosofia kantiana e que se acham à base do problema do ceticismo em SE/Co. Ext. III §3. No entanto, enfatizei que, na terceira Consideração extemporânea, Nietzsche está sobretudo preocupado com a letalidade e periculosidade para a vida humana - aos pensadores e, potencialmente, à inteira cultura da época - em relação ao problema da educação, à sua compreensão do filósofo e sua crítica à filosofia acadêmica. Também tentei demonstrar que, nos escritos de juventude, Nietzsche define o papel do filósofo por oposição ao ceticismo. Tal papel, defendi, consiste principalmente em elaborar uma sabedoria capaz de fornecer uma orientação à vida.

Para concluir, gostaria de sugerir que a concepção nietzschiana de ceticismo presente em Schopenhauer como educador também é importante para melhor compreender e apreciar o problema cético nos escritos posteriores de Nietzsche. Em Ecce homo, ele salienta 
a relevância da terceira Consideração extemporânea para o seu amadurecimento como pensador, reconhecendo que "aquilo que está basicamente em discussão não é 'Schopenhauer como educador', senão que seu oposto, "Nietzsche como educador" (EH/EH, As extemporâneas 3, KSA 6.320). O que Nietzsche diz, creio, deveria ser levado a sério. E isso é particularmente verdadeiro no caso de sua concepção de ceticismo. Em realidade, ao longo de seus escritos, Nietzsche associa contínua e coerentemente - ainda que de maneiras distintas - o ceticismo a Kant. ${ }^{98}$ No primeiro capítulo de Humano, demasiado humano, "Das primeiras e últimas coisas", Nietzsche altera radicalmente sua avaliação acerca do ceticismo, mas continua a afirmar a tarefa da filosofia em relação a ele. Em 1878, ele anuncia a provável vitória do ceticismo como uma forma de pensar (e viver) na modernidade, inclusive reputando a aquisição de "desconfiança em relação ao inteiro modo metafísico de explicar as coisas" um sinal de maturidade intelectual (Cf. MA I/HH I 17, KSA 2.38). Agora, Nietzsche chega a considerar como tarefa da filosofia, em consonância com a ciência, lançar "dúvidas sobre o consolo propiciado pela metafísica, religião e arte" (Cf. MA I/HH I 251, KSA 2.209). Ademais, nos póstumos dos anos de 1880, Nietzsche volta a associar o ceticismo ao desespero, mas, desta feita, operando uma distinção entre um ceticismo desesperador e um ceticismo experimental $(C f$., por exemplo, NF-1880, 6[356]; em relação a GS 51). Por fim, tal como mencionei, o problema do ceticismo em SE/ Co. Ext. III $§ 3$ antecipa e vincula-se ao problema do niilismo nos escritos de maturidade.

$98 C f$. , por exemplo, HH/HH 21, KSA 2.42; VM/OS 27, KSA 2.391; M/A 142, KSA KSA 3.133; Nachlass/FP 1884, 25[121], KSA 11.45; Nachlass/FP 1885, 2[161], KSA12.143; Nachlass/FP 1885, 34[221], KSA 11.496; Nachlass/FP 1885, 34[82], KSA 11.445; Nachlass/FP 1885, 42[6], KSA11.696; Nachlass/FP 1887, 9[3], KSA 12.340; Nachlass/FP 1888, 14[107], KSA 13.285; Nachlass/FP 1888, 15[28], KSA 13.422; GD/CI Como o "verdadeiro mundo" acabou por se tornar em fábula 2, KSA 6.80; AC/AC 10, KSA 6.176; AC/AC 12, KSA 6.178.

Cad. Nietzsche, Guarulhos/Porto Seguro, v.40, n.3, p. 115-170, setembro/dezembro, 2019. | 165 
Serini, L.

\title{
Nietzschean Scepticism Conception in Schopenhauer as Educator
}

\begin{abstract}
This article aims at clarifying Nietzsche's conception of scepticism in Schopenhauer as Educator - especially in light of its third section (§3). Without ignoring Nietzsche's principal concerns within his early writings as a whole, as well as their post-Kantian hermeneutic framework, the text intends to highlight that, in the third Untimely meditation, Nietzsche is principally concerned with the detrimental consequences of scepticism for philosophy (and philosophers) and potentially for the entire culture of the age, so that he would already be committed to creating a kind of wisdom capable of neutralize such a dangerousness, providing a guidance for our most deep and real vital problems.
\end{abstract}

Keywords: Schopenhauer, education, scepticism, post-Kantianism.

\section{Referências}

ANSELL-PEARSON, Keith. The Question of FA Lange's Influence on Nietzsche: A Critique of Recent Research from the Standpoint of the Dionysian. In: NietzscheStudien 17. Berlim/Nova York: De Gruyter, 1988, pp. 539-554.

. Holding on to the sublime: Nietzsche on philosophy's perception and search for greatness. In SIEMENS, H. W.; ROODT, V. (org.): Nietzsche, Power and Politics: Rethinking Nietzsche's Legacy for Political Thought. Berlin/Nova York: De Gruyter, 2008, pp. 767-99.

. Nietzsche. In: JOSEPH, F; REYNOLDS, J.; WOODWARD, A. (org.) The Bloomsbury Companion to Existentialism. London: Bloomsbury, 2014.

. Nietzsche’s Search for Philosophy. Londres: Bloomsbury, 2018.

BEISER, Fredrick. The Fate of Reason. Cambridge: Harvard University Press, 1987.

. Neo-Kantianism. In: FORSTER, M. N.; GJESDAL, K. (org.). The Oxford Handbook of German Philosophy in the Nineteenth Century. Oxford: Oxford University Press, 2015, 282-298.

BERRY, Jessica. The Pyrrhonian Revival in Montaigne and Nietzsche. In: Journal of the History of Ideas 65(3), 2011, pp. 497-514.

166 | Cad. Nietzsche, Guarulhos/Porto Seguro, v.40, n.3, p. 115-170, setembro/dezembro, 2019. 
A concepção nietzschiana de ceticismo em Schopenhauer como educador

Nietzsche and the Ancient Skeptical Tradition. Nova York: Oxford University Press, 2014

BETT, Richard. Nietzsche on the Skeptics and Nietzsche as Skeptic. In: Archiv für Geschichte der Philosophie 82 (1): 2000, pp. 62-86.

BRUSOTTI, M.; SIEMENS, H. (org.) Nietzsche, Kant and the Problem of Metaphysics. London: Bloomsbury, 2017.

BÜRGY, M. Prolegomena zu einer Psychopathologie der Verzweiflung. In: Der Nervenarzt 78(5), 2007, pp. 521-529.

BUSELLATO, Stefano. Nietzsche e lo scetticismo. Macerata. Eum, 2012

CONSTÂNCIO, João. The Consequences of Kant's First Critique. In: BRUSOTTI, M.; SIEMENS, H. (org.) Nietzsche, Kant and the Problem of Metaphysics. Londres: Bloomsbury, 2017, pp. 103-138.

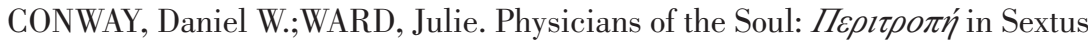
Empiricus and Nietzsche. In: CONWAY, D.W.;REHN, R. (org.) Nietzsche und die Antike Philosophie. Trier: Wissenschaftlicher Verlag, 1992, pp. 193-223

DOYLE, Tsarina. Nietzsche on Epistemology and Metaphysics. Edinburgo: Edinburgh University Press, 2009.

EMERSON, R. W. Circles. In: Essential Writings of Ralph Waldo Emerson. New York: Modern Library Edition, 2000, pp. 252-262.

FORSTER, Michael. Kant and Skepticism. Princeton and Oxford. Princeton University Press. 2008.

FRANKS, Paul W. All or Nothing: Systematicity, Transcendental Arguments, and Skepticism in German Idealism. Cambridge/London: Harvard University Press, 2005.

GARDNER, Sebastian. Schopenhauer. In: FORSTER, Michael; GJESDAL, Kristin (org.). The Oxford Handbook of German Philosophy in the Nineteenth Century. Oxford: Oxford University Press, 2015, pp. 108-136.

GJEDAL, Kristin. 'Bildung'. The Oxford Handbook of German Philosophy in the Nineteenth Century. Edited by Michael N. Forster and Kristin Gjesdal. Oxford. Oxford University Press, 2015, pp. 695-719.

Cad. Nietzsche, Guarulhos/Porto Seguro, v.40, n.3, p. 115-170, setembro/dezembro, 2019. | 167 
Serini, L.

GUYER, Paul. Kant. Oxford/Nova York: Routledge, 2006.

HILL, Kevin R. Nietzsche's Critique: The Kantian Foundation of His Thought. Oxford/ Nova York: Oxford University Press, 2003.

JANAWAY, Christopher. Schopenhauer as Nietzsche's Educator. In: JANAWAY, Christopher (org.). Willing and Nothingness. Oxford: Clarendon Press, 1998, pp. 13-36.

KANT, Immanuel. Critique of Pure Reason. Trad. Paul Guyer e Allen W. Wood. Cambridge: Cambridge University Press, 1989.

LANGE, Friedrich Albert. History of Materialism and Criticism of Its Present Importance. Trad. Ernest Chester Thomas. Oxford/Nova York: Routledge, 2000.

LAURSEN, John. Carl Friedrich Stäudlin's Diagnosis of the Political Effects of Skepticism in Late Eighteenth-Century Germany. In: LAURSEN, J.; PAGANINI, G. (org.). Skepticism and Political Thought in the Seventeenth and Eighteenth Centuries. Toronto: The University of Toronto Press, 2015, pp. 274-286.

LUPO, Luca (2019). Pour une généalogie du relativisme nietzschéen. In: STELLINO, Paolo;TINLAND, Olivier (org.) Nietzsche et Le Relativisme. Paris: Vrin, pp. 119-142.

MEHIGAN, Tim. Heinrich von Kleist: Writing after Kant. Suffolk: Boydell and Brewer, 2011, pp.15-32.

MINER, Robert. Nietzsche and Montaigne. Londres/ Nova York: Springer, 2018.

MITCHESON, Katrina. Scepticism and Self-Transformation in Nietzsche - On the Uses and Disadvantages of a Comparison to Pyrrhonian Scepticism. In: British Journal for the History of Philosophy 25(1), 2017, pp. 63-83.

NIETZSCHE, Friedrich. Sämtliche Briefe: Kritische Studienausgabe (KSB). Berlim/ Nova York: De Gruyter, 1986.

. Sämtliche Werke. Kritische Studienausgabe (KSA). Berlim/Nova York: De Gruyter, 1999.

. Sämtliche Werke. Kritische Gesamtausgabe (KGW). Berlim/Nova York: De Gruyter, 1995.

168 | Cad. Nietzsche, Guarulhos/Porto Seguro, v.40, n.3, p. 115-170, setembro/dezembro, 2019. 
. On Schopenhauer. In: NEHAMAS, A.;GUESS, R. (org.). Writings from the Early Notebooks. Tradução de Ladislaus Löb. Cambridge: Cambridge University Press, 2009.

. Fate and History. In: ANSELL-PEARSON, Keith; LARGE, Duncan (org.). The Nietzsche Reader. Oxford: Blackwell, 2006 (a), pp. 12-15.

. Pre-Platonic Philosophers. Trad. Greg Whitlock. Urbana/ Chicago: University of Illinois, 2006 (b).

.Unfashionable Observations. Trad. Richard Gray. Stanford: Stanford University Press, 1995.

PARUSH, Adi. Nietzsche on the Skeptic's Life. In: Review of Metaphysics 29 (3), 1976, pp. 523-542

POELNER, Peter. Nietzsche and Metaphysics. Oxford: Oxford University Press, 1995

REGINSTER, Bernard. The Affirmation of Life: Nietzsche on Overcoming Nihilism. Cambridge: Harvard University Press, 2006.

SANTINI, Carlotta. Nietzsche und der antike Skeptizismus. In: Nietzsche-Studien 42, Berlim/Nova York, 2013, pp. 368-274.

SELLARS, John. What is Philosophy as a Way of Life?. In: Parrhesia 28, 2017, pp. $40-56$.

SCHOPENHAUER, A. The World as Will and Representations. Trad. E. F. J. Payne. Nova York: Dover, 2 Vols., 1969.

. Parerga and Paralipomena. Trad. E. F. J. Payne. Oxford: Clarendon Press, 2 Vols., 1974 (a).

. Aphorisms on the Wisdom of Life. In: Parerga and Paralipomena. Trad.

E. F. J. Payne. Oxford: Clarendon Press, Vol.I, 1974 (b).

.On Philosophy at the Universities In: In: Parerga and Paralipomena. Trad.

E. F. J. Payne. Oxford: Clarendon Press, Vol.I, 1974 (c).

. On the Learning and the Learned. In: Parerga and Paralipomena. Trad. E. F. J. Payne. Oxford: Clarendon Press, Vol.II, 1974 (d). 
Serini, L.

. On Education. In: Parerga and Paralipomena. Trad. E. F. J. Payne. Oxford: Clarendon Press, Vol. II, 1974 (e).

.On Thinking for Oneself. In: Parerga and Paralipomena. Trad. E. F. J. Payne. Oxford: Clarendon Press, Vol.II, 1974. (f)

SCOTT, D. F. S. Heinrich von Kleist's Kant Crisis. In: The Modern Language Review 42(4), 1947, pp. 474-484

SOMMER, Andreas Urs. Nihilism and Skepticism in Nietzsche. In: ANSELLPEARSON, Keith (org.). A Companion to Nietzsche. Oxford: Blackwell, 2006, pp. $250-269$.

SOMMER, Andreas Urs. Friedrich Nietzsche. In: MACHUCA, Diego E.; REED, B. Skepticism: From Antiquity to the Present. Londres: Bloomsbury, 2018, pp. 442-453.

STACK, George. Lange and Nietzsche. Berlim/Nova York. De Gruyter, 1983.

. Nietzsche and Emerson an Elective Affinity. Athens/Ohio: Ohio University Press, 1992.

ZAVATTA, Benedetta. From Pure Reason to Historical Knowledge: Nietzsche's (Virtual) Objections to Kant's First Critique. In: BRUSOTTI, M.; SIEMENS, H. (org.) Nietzsche, Kant and the Problem of Metaphysics. Londres: Bloomsbury, 2017, pp. 45-70.

Individuality and Beyond: Nietzsche Reads Emerson. Oxford: Oxford University Press, 2019.

Recebido em 05/09/2019

Aceito em 10/11/2019

170 | Cad. Nietzsche, Guarulhos/Porto Seguro, v.40, n.3, p. 115-170, setembro/dezembro, 2019. 